\title{
Literature as Antidote: Reflections on Don DeLillo's Falling Man
}

\author{
Salah el Moncef
}

\author{
University of Nantes, 2, rue du Général Meusnier, F-44000 Nantes, France
}

\begin{abstract}
This essay proposes an interpretation of Don DeLillo's Falling Man based on a combination of textual analysis and contemporary theoretical approaches to the specific questions of trauma, grief, and posttraumatic healing as well as the more general question of the status of the subject in a postmodern context marked by increasing globalization and transnational interactions. This multidimensional interpretive approach makes it possible to theorize one of the central metanarrative questions posed by DeLillo's novel: the potential function of the postmodern novel as an antidote against various expressions of contemporary angst, such as the dread of terrorist violence or the fear of aging and age-related maladies. In exploring the significance of a double esthetic articulation in DeLillo's novel (an esthetic of estrangement and an "esthetic of disappearance"), the essay analyzes the author's representation of his characters' varying reactions to terror-related trauma and the role of the imagination in such reactions. While Falling Man represents subjective experiences of trauma and loss in painful and at times shocking ways, its dissection of the imaginary dimension of trauma also presents its readers with the possibility of incorporating various effects of traumatic experience into cohesive and constructive strategies of self-reassessment, grief management, and healing.
\end{abstract}

Keywords: 9/11 terrorist attacks, Alzheimer's, terrorism, trauma, grief, PTSD, posttraumatic recovery.

Some there are who through fear anticipate the hangman: like him whose eyes being unbound to have his pardon read to him, was found dead upon the scaffold by the stroke of imagination.

\section{Michel de Montaigne, "Of the Force of Imagination"}

Now it is an important advance in selfprotection when [a] traumatic situation of helplessness is not merely awaited but is foreseen, anticipated.

Sigmund Freud, The Problem of Anxiety

If all time is eternally present

All time is unredeemable.

\section{T. S. Eliot, Burnt Norton}

\section{INTRODUCTION}

\section{Trauma, Defamiliarization, and the Esthetic of Disappearance}

Don DeLillo's Falling Man begins with a ruthlessly detailed description of the 9/11 tragedy: a sudden descent into a terrifying scene of chaos that is meant both to shock and unsettle us as we become immersed in a world so confusing in its disarray that we find ourselves witnessing it as an opaque thing in itself-an

*Address correspondence to this author at the University of Nantes, 2, rue du Général Meusnier, F-44000 Nantes, France; Tel: + 33 (2) 403574 40;

E-mail: salah.elmoncef@free.fr incomprehensible singularity that overtakes the senses, overwhelms the mind, and haunts the imagination. For the reader who finds herself plunged into the opening pages of Falling Man, the shocking power of this initial odyssey into the hell of the $9 / 11$ attack is derived almost exclusively from the sheer brutality of the catastrophe (its unmediated violence), making of DeLillo's novel a dramatic instance of what Maurice Blanchot famously termed the "writing of disaster"-a form of literary exploration premised on the reader's descent into an alienating world of "infinite menace," of violence that "has gone beyond all boundaries," encompassing the totality of public space, the totality of the quotidian and its ordinary markers of familiarity, the totality of subjective consciousness (1980:7). This is the world of radical boundary transgression and estrangement ${ }^{1}$ into which Keith Neudecker finds himself almost literally ejected-a world where "all that is solid melts into air" (Marx and Engels 1969:16), a phrase echoed almost word for word by DeLillo's narrator. The postmodern urban setting into which we find ourselves so violently projected with the victim is very much akin to a building subjected to extreme impact propagation and heat: it is a deeply shocked and shaken setting in which "what is solid" indeed "melt[s]," leaving us bereft of the reliable reality that we

\footnotetext{
${ }^{1}$ In this essay, I will be using the term "estrangement" in reference to Fredric Jameson's elaboration on Victor Shklovsky's ostranenie (Jameson 1974:50 54).

2"All fixed, fast-frozen relations, with their train of ancient and venerable prejudices and opinions, are swept away, all new-formed ones become antiquated before they can ossify. All that is solid melts into air, all that is holy is profaned, and man is at last compelled to face with sober senses his rea conditions of life, and his relations with his kind" (Marx and Engels 1969:16). See also Marshall Berman's use of the Marxian phrase to theorize the experience of modernity (1988).
} 
have always taken for granted (DeLillo 2011:127). As we revisit the horror of 9/11 from the victim's point of view, we begin to contemplate this setting as a distorted urban theater subjected by DeLillo to an esthetic of estrangement, a mode of representation through which the familiar becomes uncanny in its sudden otherness (Freud 2003), both known and alien in its abrupt disfigurement by terrorist destruction-the defacement of the once-taken-for-granted commonality of public space with its markers of collective identity. Seen through Keith's alienated, traumatized eyes, the "world now" has become an unmarked, indefinite, primal "it"-engulfed in chaotic ash and smoke, corporeally lived rather than cognitively apprehended, experienced as a pure unmediated thing in itself-as if DeLillo's emblematic man has suddenly found himself thrown into an eerie spatiotemporal dimension, a setting of primitive violence and senseless destruction, like a raging volcano or a howling sandstorm:

It was not a street anymore but a world, a time and space of falling ash and near night. He was walking north through rubble and mud and there were people running past holding towels to their faces or jackets over their heads.... This was the world now. Smoke and ash came rolling down streets and turning corners ... seismic tides of smoke, with office paper flashing past, otherworldly things in the morning pall.... There were shoes discarded in the street, handbags and laptops.... Paper cups went bouncing oddly by.... There was something else then, outside all this, not belonging to this, aloft. He watched it coming down. A shirt came down out of the high smoke, a shirt lifted and drifting in the scant light.... They ran and then they stopped ... standing there swaying, trying to draw breath out of the burning air ... and the paper massed in the air, contracts, resumes blowing by, intact snatches of business, quick in the wind.... There were the runners who'd stopped and others veering into sidestreets. Some were walking backwards, looking into the core of it, all those writhing lives back there.... In time he heard the sound of the second fall. $\mathrm{He}$ crossed Canal Street and began to see things, somehow, differently.... There was something critically missing from the things around him. They were unfinished, whatever that means. They were unseen, whatever that means, shop windows, loading platforms, paint-sprayed walls. Maybe this is what things look like when there is no one here to see them. (DeLillo 2011:3-6)

The catastrophic opening of DeLillo's novel is an infernal scene of primal chaos and erasure in which we witness the familiar turn into an indecipherable thing-initself, vanishing into fogs of oblivion not unlike Alzheimer's-another embodiment of loss and disappearance deftly folded into the narrative in the form of a leitmotif, allowing the author to further underscore his association of terrorism with the scarring of the collective mind, its subjection to the debilitating power of "loss" and "diminishing returns" (DeLillo 2011:60). Therein lies the intricate meaning of the other key esthetic mode developed by DeLillo in his masterful overture of terror: his experimentation with an "esthetic of disappearance" (Virilio 1989) that allows him to establish, early on in the narrative, an overdetermined metonymic relationship between speed, the traumatic erasure of two pillars of familiarity from the city's skyline, and the capacity of a terrorist attack to rapidly and severely impair the human mind by inflicting sudden physical loss and mental disruption. ${ }^{3}$ The author's combination of two esthetic effects-an esthetic of estrangement and an esthetic of disappearance-is at the heart of the novel's vision of the post-9/11 "now" that we are called upon to witness as we begin to experience New York differently-no longer as a city only but as an uncanny new world in which the traumatized and alienated mind of a Keith struggling with cognitive and existential loss becomes an expression of humanity grappling with the diminishing returns and disorientation that it experiences as it finds itself ejected into the space of an unprecedented public domain, a domain where terrorism with its "fatal strategies" is becoming an increasingly common form of social expression (Baudrillard 1983:49-70, 88-94). To make us, as readers, partake of the sense of grief and disorientation that comes with Keith's loss is, in other words, also to make us engage in a process of mourning our own loss of the public sphere as we once knew it: the

${ }^{3}$ Here, I am thinking of Paul Virilio's theorization of the linkages between speed and representation (1989) but also of his work on the state of emergency (1977). See also Virilio's reflections on modernism and hypermodernism (Armitage 1999). 
catastrophic, tragic disappearance of two loved architectural landmarks, two pillars of the collective cultural memory of New Yorkers, marks the vanishing of our sense of a public domain requisitely founded on civility, empathy, and "responsibility for the other" (Levinas 1961:91-98; 1982:11-12, 18-23). ${ }^{4}$ In his haunting reference to Marx and Engels, DeLillo makes it painfully obvious that the new post-9/11 reality extends far beyond the confines of one city: it is a historic symptom concomitant with the tangled, dark underside of a globally interrelated world-an increasingly estranging late capitalist world that is yet to be mapped and in which "what is solid [seems to] melt" into air (DeLillo 2011:127). We are all New Yorkers.

This essay offers to explore DeLillo's innovative conception of Falling Man as a form of antidotal literature-a novelistic venture in which the author experiments with the stream-of-consciousness technique to project the new possibilities that lie ahead for postmodern subjectivity in its struggle with the various material, symbolic, and imaginary manifestations of traumatic loss. ${ }^{5}$ In dealing with the author's experiment, I propose to pursue two lines of inquiry that I will develop in this two-part essay: first, I will focus on the narrative status of Falling Man as a tentative anatomy of the human mind in the wake of deep trauma, an attempt to dissect the terrorized imagination as it struggles defensively to envision and anticipate the reappearance of the terrorist other through various fantasized catastrophe scenarios in which the terrorist is recurrently projected as an uncanny spectral trace infiltrating the quotidian; second, I will elaborate on the assumption that DeLillo's chronicle of $9 / 11$ explores the subjective experience of the terrorist event in terms of an active core of anxiety that gradually comes to determine the subject's sense of temporality-a dynamic kernel of dread embedded in memory and charged with traumatic residues from the past that occupy the totality of the present and loom over the future as an alwaysabout-to-occur menace. In Falling Man, the key protagonists' various struggles with this core of anxiety at the center of their existence post-9/11-their different quests for remedies and compensations against shock and terror-represent a central element

\footnotetext{
${ }^{4}$ See also Claude Lefort on the "disappearance of the figure of the other as fellow" in the contemporary form of the social contract (1978:177 ff.).

${ }^{5} \mathrm{My}$ reflections on literature as antidote have been developed partly in relation to Jacques Derrida's theorization of Plato's pharmakon (1981:128-171). See also Silvia Caporale Bizzini's reflections on grief and remembrance (2010).
}

in the novel's anatomist approach to trauma and the possible antidotes against its devastations.

As far as the first line of inquiry is concerned, DeLillo's investigation into the impact of terror on the imagination revolves around a powerful operative metaphor highlighted by the author early on in the novel: the projected presence/absence of Bill Lawton with his insidious powers - his capacity to haunt the sky and the city while eluding full observation, the everimpending possibility of his horrific return. The central metaphoric concept of Bill Lawton is fundamental to Falling Man's vision of $9 / 11$ in that it allows the author to prioritize the twin processes of projection and anticipation around which he develops his approach to the imaginary dimension of trauma-a cumulative approach articulated in several analogous instances that operate like variations on a key theme. One of these instances is the Neudecker family, who become confronted with the "twisted powers of imagination"" and their fluid capacity to constantly project the destructive reemergence of the terrorist other: the "'myth of Bill Lawton"' and his dreaded reappearance, the catastrophic projections of the scarred and inflamed imagination "'[s]earching the skies for Bill Lawton," confirming his existence in spectral form the better to anticipate and manage his inhuman devastations (DeLillo 2011:71-72). An occurrence that one does not "know what to call," the unsettling presence/absence of the terrorist as a specter haunting the city is ultimately an imaginary projection that originates primarily in the other scene of the unconscious, a negative fantasy associated with a traumatic upsetting of the habitual order of things (DeLillo 2011:64). Therein lies the nexus of eerie negative associations developed around the Bill Lawton referent, which gradually becomes emblematic of a radical destructive agency that seeks no negotiation or compromise or even belligerent engagement-solely the annihilation of collective and subjective memory in the most unpredictable way possible. This specifically apocalyptic cast given to terrorist disaster-an unforeseeable catastrophic incident leading to erasure of a way of life and its markers of collective identity-allows DeLillo to articulate the terrorist event within a shifting dialectical field where the various actors of his novel are pitted against not only the effects of disaster and the dread of disappearance, but also against the irrational projections and fantasies those effects engender in their own imaginations. These somber intimations of apocalypse and amnestic erasure correlate with 
another instance, or variation: the "hauntological" (Derrida 2006) status of Bill Lawton as a symbol and as a highly fluid intersubjective symptom-a ghostly entity with a paradoxical ontological aspect (both seen and unseen). As a being invested with baffling supernatural powers, the "mythical" figure becomes a ubiquitous yet hidden evil force literally hovering over the city-always awaited, always about to strike again; a spectral presence endowed with the occult power to invade people's homes, working its way quite literally back into the picture (Nina's painting), imposing itself as a ghostly reminder of the tragic past (DeLillo 2011:49). Ultimately, whether as menace in the sky or as pictorial palimpsest, the spectral trace of the terrorist other in Falling Man evolves into a terrifyingly opaque imaginary index fraught with a dread and an indecipherability that quickly turn into an affective "surplus" of which DeLillo's characters strive to "divest" themselves as they come to grapple with the realization that hell is the other, ${ }^{6}$ especially when the other becomes infinitely cruel, his face and his words and his motives impossible to integrate within the realm of the known and the familiar. Dealing with the impossibility of understanding the other even as one coexists with them is one of the most significant problems developed by DeLillo in relation to the question of Middle Eastern alterity. The problematic of otherness in the age of terror will be developed in the first part of this essay after the segments that deal with the terrorist attacks as catastrophic event and the hauntological status of the terrorist.

As to the second line of inquiry, which will be developed in the second part of this essay, DeLillo's experimentation with the novel as antidote against the dread of a recurrence of traumatic experience is closely related to his exploration of the various subjective imperatives that his characters are confronted with as they come to terms with the simultaneous challenges of grief and posttraumatic stress disorder. The second part of this essay consists of three sections that deal with three imperatives that figure prominently in DeLillo's novel: denial (Keith's career and lifestyle change); the work of mourning, or the right remembering (Lianne's constructive struggle with the loss of her parents and the loss of the $9 / 11$ victims); the

\footnotetext{
${ }^{6}$ In Blanchot's words: "The other, according to Levinas, is burdensome, but isn't this also Sartre's perspective? The nausea that we get not from a lack of being, but from an excess of being, a surplus of which I want to divest myself" (1980:41).
}

right forgetting (Lianne's redeeming decision to put her fears and her suffering behind her once and for all). ${ }^{7}$ In Keith's decision to partially relocate to the hyperreal, post-historical Las Vegas and pursue the career of professional poker player, one can discern a common instinctive motive: the urge to physically and mentally flee the source of pain-in this case the urban setting associated with the traumatic past event. Unlike her husband Keith, however, Lianne chooses to heed a quite different urge-that for self-preservation and healing. While pained and powerless during her confrontations with Falling Man's reenactment of a particularly traumatizing aspect of the attacks, she is also driven by the more anchored and systematic imperative of remembrance and use of the present as a scene on which to stage the past and engage her trauma through recollection and reflection. As the novel evolves toward Lianne's epiphanic moment inside the church, the dictates of the work of mourning slowly give way to a healthy motive determined by her ego's need to live fully and affirm a vital exigency: the desire to reach a measure of healthy forgetting by exorcising her future of the past's spectral fears (the dread of recurrent terror associated with the primal scene of trauma, the dread of hereditary illness and a demeaning death).

In a gesture that recalls her husband's encounter with the memory of the dead around Ground Zero, the place of contemplation and communion in which Lianne comes to remember her dead mother and seek appeasement (a church) is a scene equally marked by death and charged with the interstitial presence of the dead-both here and there, present and absent, between "un-being and being" (Eliot 1971:181); an anamnestic locus, in sum, that exerts immense power over the imagination-a symbolically charged site where the "dead [are] everywhere ... in the air" (DeLillo 2011:25). However, while Keith senses torment and a measure of revulsion in recalling the 9/11 dead near Ground Zero, Lianne finds pacified affinity and a binding spirit of communion with their presence: "breathing the dead" and feeling them "in the walls," she realizes that "the human ruins" bring "intimacy and ease" as she begins to envision life after the work of mourning (DeLillo 2011:233-34). Similarly, the shifting scene on which the performance artist David Janiak

\footnotetext{
${ }^{7}$ My use of the concept of the right forgetting in this essay has been partly inspired by the late Paul Ricoeur's observations on the capacity of the pacified subject to achieve appeasement toward time and history as well as the possibility of a "happy forgetting" (2004:494 ff.).
} 
(Falling Man) stages his own version of the work of mourning seems to be another site of the imagination that recalls the ubiquity of the dead and the necessity for the living to learn to relate to them, ${ }^{8}$ to learn to develop a salutary acceptance of their mortality through contemplation of the fact of death. The inherent hazards of such contemplation seem to figure as a key metaperformative offshoot of the tacit message conveyed by the performance artist who lends his name to the title; for his performance involves nothing less than a naked, vulnerable, and ultimately always unguarded exposure to the symptomatic substance of one's fear of death. Our own horrified exposure to David Janiak is quite similar to Lianne's divided reaction to the man's work: seen from her point of view, the performer appears to be an artist-philosopher who practices a deeply ambiguous, deeply opaque art of confrontation with death through reiteration ${ }^{9}$ of an emblematic (and deeply traumatic) memory from the 9/11 tragedy - the memory of the innocent victims who preferred to jump out of the Twin Towers rather than meet their demise in the disintegrating inferno that the buildings were turning into:

She [had] heard of him, a performance artist known as Falling Man. He'd appeared several times in the last week, unannounced, in various parts of the city, suspended from one or another structure, always upside down, wearing a suit, a tie and dress shoes. He brought it back, of course, those stark moments in the burning towers when people fell or were forced to jump.... There were people shouting up at him, outraged at the spectacle, the puppetry of human desperation, a body's last fleet breath and what it held. It held the gaze of the world, she thought. There was the awful openness of it, something we'd not seen, the single falling figure that trails a collective dread, body come down among us all. And now, she thought, this little theater piece, disturbing enough to stop traffic and send her back into the terminal. (DeLillo 2011:33)

\footnotetext{
${ }^{8}$ Here it is worth recalling Derrida's argument that the work of mourning as a process of claiming one's bond with the dead is not without its limitations and risks (2001:44 ff.)

${ }^{9}$ In Freudian terms, this process is an attempt at "psychically prolong[ing]" the "existence" of the victims in order to dedicate enough time to the process of reflecting on the departed in particular and on the fact of our ephemerality in general (Freud 1978:244)
}

For all the impenetrable ambiguity of his artistic practice, what Falling Man ends up teaching Lianne and us through his tacit method-one that is ultimately rooted in both an esthetic and a philosophy of the "unpresentable"10 (Lyotard 1985:80)-is a twofold lesson that is central to the woman's work of mourning: on one level, Falling Man's work is an artisticpedagogical practice based not so much on an esthetic of disappearance as on the contemplation of disappearance-a gripping balletic performance that manages to capture the fugacious and freeze it in midair for us to reflect upon (the "fleet breath" that human life represents in the totality of space-time); on another level, Falling Man teaches a mode of thought grounded in a fully contextual, anti-conceptual philosophy, a philosophy premised on antidotal confrontation with the universal fact of our mortality through a "bringing back" of the traumatic event, an anamnestic reiteration shorn of all metadiscourse - the direct toxic substance of our fear devoid of all explanation, pure unpresentable traumatic thingness (DeLillo 2011:33). Through an inextricable embedding of both levels in his performances, Falling Man seems to propose an art of shock and confrontation that leaves New Yorkers no choice but to reflect on Montaigne's dictum: to philosophize one's human destiny is to learn to come face to face with the fact that "'being human [is] being mortal'" (DeLillo 2011:111); to learn to study mortality and be at home with the study of it (Montaigne 2009); in short, to learn to die by proxy and by reflection in this moment when the fact of mortality is frozen in time by the artist of "stationary fall" (DeLillo 2011:34). Proposing an antidotal approach to mortality by presenting the unwilling spectator with vicarious death (as opposed to death itself), David Janiak puts forth an iterative performance that may be interpreted as pure pharmakon: an uncanny, almost always alienating attempt to inoculate his fellow humans against the "fleetness" of existence through an esthetic-existential representation of disappearance.

\section{"Twisted Powers": Trauma, Derealization, and the Specter of the Terrorist other}

Not unlike the otherworldly shirt that bookends DeLillo's odyssey into the world of trauma, the haunting ghostly phenomenology of the terrorist event hovers

\footnotetext{
${ }^{10}$ See also Lyotard's more specifically esthetic reflections on representation and the unpresentable (1991:119-28), Jean-Joseph Goux's concept of the "non-figurable" (1978:18-9, 65-99), and Giovanna Borradori's dialogues with Derrida and Habermas (2004)
} 
over the entire novel and its alienated vision of the post-9/11 subject. Through Keith, we witness the desecrated familiar begin to succumb to the uncanny effects of estrangement, becoming a spectral shadow of itself, contaminating the protagonist's mindscape with all its alienating power. Similarly, the subjective perceptions of Keith that we get in the immediate aftermath of the tragedy (Lianne and the truck driver's points of view) are significant illustrations of the narrative strategies through which DeLillo seeks to develop pertinent structural homologies between the ghostly metamorphosis of material reality in the outer world and the sense of derealization experienced by his characters in the inner world of their imaginations. Both Lianne and the truck driver, in their own different ways, see in Keith an uncanny, derealized apparition more than a material human presence, with Lianne apprehending her post-9/11 husband as the vision of a ghostly being-a man "up from the dead" and insubstantial as "smoke"; a "hovering presence ... not quite returned to his body yet" (DeLillo 2011:8, 59). For his part, the truck driver "examine[s]" Keith with stupefaction, perceiving the shaken and disoriented victim as a primal "man scaled in ash, in pulverized matter" (DeLillo 2011:6). As for Keith's perception of himself, the poignant self-assessment that closes chapter one is itself an apt statement on the correspondence between the unreal ghostliness of the site of terror and the sense of fading ${ }^{11}$ which invades the subject that has come face to face with the traumatic impact of the event: "He tried to tell himself that he was alive but the idea was too obscure to take hold" (DeLillo 2011:6). In dealing with these initial impressions of an uncanny world seen through the subject's shocked consciousness, it is important to keep in mind the other more subtle homology between the ineffable "itness" of Ground Zero (the "core of it") and the surreal metamorphosis of the ordinary components of everyday life-"shop windows, loading platforms, paint-sprayed walls" (DeLillo 2011:5). Indeed, the latter present themselves to Keith's traumatized vision also as ineffable raw things in themselves, experienced outside the realm of verbalization and conceptualization, as if they were witnessed from the point of view of a subject whose consciousness has been distorted by a mind-altering illness: "There was something critically missing from the things around him. They were unfinished.... They

${ }^{11}$ See Jacques Lacan's conception of the fading of the subject (1966:816;
1973:159-208). were unseen... Maybe this is what things look like when there is no one here to see them" (DeLillo 2011:5, 6)..$^{12}$ Combined with such philosophical insights into the dazed consciousness of the traumatized man grappling with the itness of his new world, the esthetic of estrangement developed by DeLillo allows him to fully dramatize Keith's frail grip on material reality, a condition poignantly represented by the phantasmagoric sight of a woman's mask-like face as she stands transfixed behind the ordinary shopping cart, which becomes unsettlingly unreal instead of comfortingly familiar and ordinary (DeLillo 2011:5).

In this context, it is especially important to dwell on the relation of isomorphism between the subjective and the objective in the opening pages of Falling Man. Indeed, starting with Keith's meandering movement away from the Twin Towers, the unsettling fading of "what is solid" within the subject goes hand in hand with the dissolution of the streets themselves as objective containers of the material symbols that define social identity (DeLillo 2011:127). While we witness those material symbols literally flying by, vanishing into primal "time" and "free space," the newly emerged world into which they vanish figures as a sphere of pure thingness that marks the annulment of sociality itself with all the familiar emblems that represent its binding and stabilizing force now reduced to uncanny things devoid of a defining context-laptops, contracts, job applications, briefcases, office supplies: "The world was this as well, figures in windows a thousand feet up, dropping into free space.... [P]aper massed in the air, contracts, résumés blowing by, intact snatches of business, quick in the wind" (DeLillo 2011:4). This highly symbolized representation of a public sphere reeling from a form of anarchy that has dissolved the familiar markers of sociality is, in a way, brought to its culminating point when Keith makes his way back to his home in the vicinity of Ground Zero-a deeply metaphoric moment in its combination of effects of the uncanny with Keith's pained realization that his lawful apartment lease has been effectively annulled, rendering him officially homeless: "up from the dead" and insubstantial as "smoke" (DeLillo 2011:8), Keith experiences this return to once familiar territory as a process that is itself ghostly and insubstantial, with elements of his daily reality that were once commonplace and taken for granted brutally metamorphosed into spectral entities in an apocalyptic

\footnotetext{
${ }^{12}$ See Virilio's observations on cinema and trauma and on the cognition-altering effects of piknolepsy (1988:18-19; 1989:13).
} 
scene that is both unfamiliar ("somewhere else") and immaterial under the new veil of ashen ghastliness that has descended on everything:

The streets and cars were surfaced in ash and there were garbage bags stacked high at curbstones and against the sides of buildings. He walked slowly, watching for something he could not identify. Everything was gray, it was limp and failed, storefronts behind corrugated steel shutters, a city somewhere else, under permanent siege.... He stood ... and looked into the haze, seeing the strands of bent filigree that were the last standing things, a skeletal remnant of the tower where he'd worked for ten years. The dead were everywhere, in the air, in the rubble, on rooftops nearby, in the breezes that carried from the river. They were settled in ash and drizzled on windows all along the streets, in his hair and on his clothes. (DeLillo 2011:24-25)

In the new context of a post-9/11 world, familiar elements of the quotidian become alien and uncanny things in a nameless and indefinite "somewhere else," gaining a new unsettling aura even while maintaining some of their original familiarity (DeLillo 2011:25). In the "otherworldly" setting of estrangement surveyed by Keith, even the air has become impossible to take for granted-a reminder of the "burning air" in the infernolike "core" of Ground Zero and of the nameless thingness (the "it") that the buildings have turned into (DeLillo 2011:4). What remains of the two towers has now been metamorphosed into a living symptom of Keith's new condition: his struggle to self-represent and self-conceptualize the horror of the event that has cataclysmically transformed his private history and the history of the city. The ghostly visual textures of this scene of banishment have also become linked with death and the memory of death, which is now seen no longer as an abstract idea but as an incarnate anamnestic trace imbedded in every dimension of the real: the "dead were everywhere" (DeLillo 2011:25). Thus, for all the eerie references to the ghostly intangibility of the setting, this moment of return to the repressed-of diving into the wreck, to use Adrienne Rich's metaphor (1984)-has taken an all too palpable turn, as Keith finds himself revisiting the nightmare of history in its incarnate materiality, quite literally, its horrifying irrepressibility: seeing the twin towers stripped of all their majesty as symbols of the cultural and economic prominence of New York City, reduced to a mass of rubble and tangled iron, Keith suddenly realizes that he has come to revisit, without any hope of closure or consolation, what Slavoj Žižek terms the "substance of the real," an ineffable material presence manifesting as the living kernel of his posttraumatic symptoms (1989:55-84).

That Keith remains confined within the limits of a horrid posttraumatic condition that cannot find a name for the horror is made painfully evident through the recursive ending of the novel and our sudden, unexpected reimmersion into the chaos of the attack. ${ }^{13}$ By sheer force of reiteration, DeLillo manages to highlight not only the persistence with which the terrorist event is retrospectively projected in Keith's consciousness, but also the brutality of the trauma's recurrence in memory, since its effects have not been alleviated by the necessary work of mourning: "something always happening ... always in the air," like the ghost of Bill Lawton and the returning planes (DeLillo 2011:78). (To put it in T. S. Eliot's terms, the time of Keith's unprocessed trauma-his past-has become "eternally present" in his consciousness, making it impossible for him to "redeem" the past and achieve a measure of wholesome distance from the destructive immediacy of his memories [1971:175].) By the same token, the persistence of the disaster, symbolized by this unexpected return to Keith's shocked consciousness at novel's end, confronts us with a world radically opposed to the sense of "unfailing" architectural and cultural permanence that we always associate with New York City-the same sense of perennity that Nina Bartos, Lianne's mother, associates with the Metropolitan Museum in a highly symbolic reflection on the importance of identity and collective memory: "She looked at what was unfailing. She liked the big rooms, the old masters, what was unfailing in its grip on the eyes and mind, on memory and identity" (DeLillo 2011:11). The chaotic otherworldliness that we witness retroactively with/through Keith at the end of Falling Man-the apocalyptic sense of an ending of all sense (Kermode 1968)-is a far cry from the serene feeling of permanence that Nina experiences. From Keith's topsy-turvy vision of the offices inside the building to the disappearance of light and visibility to the demise of any sense of self-recognition, what we are facing here is something that is quite akin to the process of fading

\footnotetext{
${ }^{13}$ Aptly, James Gourley uses the concept of the eternal return in his comments on the significance of reiteration in Falling Man (2013:78-83).
} 
and erasure characteristic of Alzheimer's disease. In short, the ominous ending crafted at great risk by DeLillo confronts us not solely with a traumatizing experience of defaced architecture and public space, but also with a far-reaching metaphor that once again highlights Keith's status as emblematic figure: the figure of a man who becomes representative of a world of radical contingency in which the possibility of material and mental erasure has become a tangible part of our postmodernity-a world, in sum, where global terror is a ceaseless menace that threatens to turn the markers of meaning and memory in our world into "vestigial" rubble and "residue[s] of smashed matter":

The only light was vestigial now, the light of what comes after, carried in the residue of smashed matter, in the ash ruins of what was various and human, hovering in the air above.... He could not find himself in the things he saw and heard.... That's where everything was, all around him, falling away, street signs, people, things he could not name. (DeLillo 2011:246)

Revisiting the metaphor of the birth of a new world that is yet to be named (DeLillo 2001:33-40), the master once again chooses imagery of outer space to highlight his book's finale, comparing the terrorist explosions to the Big Bang and the post-9/11 universe born of them to the inceptive constellations that came into being after that monumental space event. Simultaneously, the linkage to the dissociations and disconnects within the disintegrating consciousness of the Alzheimer's patient are made dramatically evident, as this recollection by Lianne shows:

She [Lianne] thought of the conversation with Dr. Apter concerning the day when Rosellen could not remember where she lived. This was an occasion that haunted Lianne, the breathless moment when things fall away, streets, names all sense of direction and location, every fixed grid of memory. (DeLillo 2011:156)

Whether it is comparable to the monumental dynamic of the Big Bang or to the cognitive shifts in the mind of the Alzheimer's victim, what we witness in the undoing of the tower's grids and the birth of Keith's new world is ultimately nothing less than the erasure-the temporal "falling away" - of the relatively orderly world that preceded it. Hence the powerful significance of the uncanny, otherworldly shirt "waving like nothing in this life": a symbol of the new world and the new life that are awaiting us after 9/11-a world where shirts fly (DeLillo 2011:246).

As we begin to delve deeper into the new world of Falling Man, we soon realize that the spectral presence of the terrorist other in New York City has become an integral part of life post-9/11, a presence that manifests as an unpredictable, incomprehensible, and highly disruptive symptomatic event that is always about to happen. Viewed from a systemic point of view, the potential eruption of the terrorist in DeLillo's novel represents the always impending possibility of a subversive symptom within a society whose evolution rests on a subtle balance between freedom and coherence: a complex combination of high levels of differentiation and fluidity with stringent criteria of logical consistency and systematism. In this sense, the terrorist's criminal resentment toward the priorities, workings, and ethos of such a society appears to be a mystifying, unexplainable driving motive that leaves most of DeLillo's protagonists at a loss to integrate what happened into a coherent narrative. There is, on the part of the terrorist, an unfathomable willingness to deny his humanity and die for the sake of disruption and transgression: the spirit of ressentiment in its worst form (Nietzsche 1989:11 ff.). In this context of utter impenetrability of the motives of the other, the ghostly figure of Bill Lawton presents itself as a symbolically fitting metaphor in a world where the terrorist becomes a spectral "hovering presence" more than a material entity; a world where New Yorkers are literally searching the skies for more weapons of destruction, searching their midst for the presence of more sleeper cells (DeLillo 2011:59). In rather terse and cryptic terms, Martin Ridnour comments on this negative power that the terrorist seems to possess facing a society based on the affirmative values of freedom, diversity, and the optimization of human potential: the sole power of the terrorist pitted against such a society is his nihilistic "willingness to die,"”14 Martin argues, his acceptance to give himself up to death; and in accepting to die for principles that are fundamentally based on nihilistic hate, the terrorist is always already a ghost "outside life": "this what happened, it's ... outside someplace, on the other side of the world.... You don't

\footnotetext{
${ }^{14}$ See Milan Zafirovski and Daniel G. Rodeheaver's observations on Islamist terrorism as "the product of antagonism to Western liberal modernity turned anti-modern nihilism" (2013: 347-361; 355). On the connections between terrorism and nihilism, see also Badiou (2004:141-64), Bayman (2003:Iv-Iviii), and Diken (2009:77-82).
} 
know what to do. Because they're a million miles outside your life. Which, besides, they're dead'" (DeLillo 2011:47, 64).

Emerging as an interstitial, "hovering presence" in a terrorized and deeply suspicious urban setting, the ghostly manifestation of the terrorist is first expressed in symbolic terms-as a spectral emanation that has suddenly come to haunt a painting on Nina's wall under the guise of palimpsest forms in the shape of the twin towers: this strange and estranging moment represents the first step in the novel's deeper exploration of the phenomenology of the spectral and its expression in a very specific aspect of fear: the dread of a traumatized consciousness projecting the terrorist event in displaced ${ }^{15}$ form within altogether different dimensions of time and reality-once again, the "twisted powers of imagination"' are crucial here, in this most uncanny moment when Lianne and Martin find themselves grappling with a marginal phenomenon manifested in the interstice between un-being and being (DeLillo 2011:59, 72). Equally important-again, from a symbolic perspective-is Martin's reference to "being back in another time zone," which becomes, in this context, a significant statement on the imagination haunted by the insurmountable ghosts of past trauma, projecting elements from a scarring past experience onto their present apprehension of reality:

.... "I keep seeing the towers in this still life."

They looked together.

Two of the taller items were dark and somber, with smoky marks and smudges, and one of them was partly concealed by a long-necked bottle. The bottle was a bottle, white. The two dark objects, too obscure to name, were the things that Martin was referring to.

"What do you see?" he said.

She saw what he saw. She saw the towers. (DeLillo 2011:49)

This incident marks the persistence of trauma in Falling Man as spectral representation-an indefinite

\footnotetext{
${ }^{15}$ On the relation between anxious anticipation and the imaginary in the traumatic process, see Freud (1936:112 ff.). See also, in a different context, Freud's seminal observations on the twin processes of "displacement" and "substitution" (1941:65).
}

projection that is "too obscure to name"; the creation of an imagination that has succumbed to the dread of recurrence (iteration), projecting the traumatic event as a palimpsest presence trapped in the margin between un-being and being, superposed over the material painting like a ghostly emanation that one remains powerless to conceptualize or name. The metaphoric subtext of this highly symbolized moment is at once subtle and poignantly persistent: aided by the twisted powers of the inflamed imagination, the terrorist insinuates himself quite literally back into the picture, his insidious agency recurring in the form of a ghostly palimpsest trace from the past inscribed onto the layers of the present, haunting them, infiltrating them, in Martin's words, like an airborne virus. The inherently paradoxical, latent, and liminal status of the terroristpresent/absent, viral, hauntological-is here given significant conceptual pertinence, one that is entirely independent of the truth content of Martin and Lianne's misperception. Hence, this key moment in DeLillo's novel is perhaps best interpreted in terms of narrativeconceptual strategy-a device that operates like a metaphysical conceit, allowing the author to convey the power of the haunted imagination to project variations on a traumatic event in the form of imaginary perceptions, transforming the subject's relationship not only to space, but also to time as she finds herself experiencing the terrorist event in the form of "something always happening ... always in the air," always projected in the mind, in an endless loop of iteration that becomes itself ghostly and interstitial, articulated within the threshold between the material and the imaginary, between un-being and being (DeLillo 2011:78).

The anticipatory power of the imagination (the links that it deftly creates between its projections and an originary traumatic event [Hodgkin and Radstone 2006:6-7, 97-103]) is dramatically rendered in another instance of misperception: Keith and Lianne's confrontation with the "ghost" of Bill Lawton-his provenance from the dark recesses of the twisted imagination in the form of a "mythical" being associated with the deadly planes (DeLillo 2011:72):

"Either way, you're saying, they're looking for more planes."

"Waiting for it to happen again."

"That scares me," she said.

"This time with a pair of binoculars to help 
them make the sighting."

"That scares the hell out of me. God, there's something so awful about that. Damn kids with their goddamn twisted powers of imagination...."

"They're searching the skies...."

"The name originates with Robert.... Robert thought, from television or school or somewhere, that he was hearing a certain name. Maybe he heard the name once, or misheard it, then imposed this version on future occasions. In other words he never adjusted his original sense of what he was hearing."

"What was he hearing?"

"He was hearing Bill Lawton. They were saying bin Laden...."

"So, together," he said, "they developed the myth of Bill Lawton...."

"Searching the skies for Bill Lawton." (DeLillo 2011:72-74)

The mondegreen, while once again a product of misperception and the twisted powers of imagination, is hermeneutically quite significant in that it highlights not only the mechanisms of creative "displacement" and "substitution" that take place in the traumatized imagination (Freud 1941:65), but also the selfprotective overwriting of the name that is impossible to accept-to name, precisely. As a result of this unacceptability, the name "bin Laden" becomes an encryption within a familiar name that helps make the dreaded presence of the unnamable less uncanny, more recognizable and therefore mentally more manageable. The traumatized children superimposing one version of reality over the too-terrible-to-accept original narrative (the fact that the towers were hit) is a process that is quite similar in its functioning to Lianne and Martin seeing the twin towers manifested in cryptic form, so to speak, as ghostly shapes superimposed over the original painting. In the children's case, the overwriting of the original name operates within an imaginary process that consists in substituting a Western name for an Arabic one in order to render the traumatic signifier "bin Laden" more acceptable and therefore intelligible and controllable. At this point, it is also worth noting that as far as the children are concerned, a similar dynamic of anticipation and selfprotective imaginary distortion is at work on the level of temporality. Indeed, the children's heartbreaking decision to protect themselves and anticipate the coming of Bill Lawton by using binoculars is a temporal strategy-a symptom of the terrorized mind in its attempt to anticipate, to project itself in the future the better to brace against disaster. From a symbolic point of view, "Searching the skies for Bill Lawton" is tantamount to scrutinizing and interrogating the future for signs and portents.

In his dissection of the effects of trauma, DeLillo manages to present us with a haunting image of terrorism as a sinister power that revolves around the existence of the terrorist in New York's collective unconscious as a "limitrophe," inassimilable entity encrypted in paintings, haunting the skies, infiltrating homes. Expressed on a less subjective level, this invasive power of the negatively mythologized other is articulated with an analogous metaphor: viruses and their capacity to propagate and spread according to time cycles that are outside the temporal rhythms of humanity. The equation of the terrorist with airborne viruses is hermeneutically pertinent to the metaphorics of hauntology developed throughout the novel: as Martin sees it, the presence of the terrorist on the margins of Western society is like "'a viral infection [that] reproduces itself outside history","16 and comes to plague the "'heart of the West"' like a contagious disease from the core of failed periphery countries that figure in the Western imaginary like so many breeding grounds for all sorts of deadly "viruses": "Martin ... spoke about lost lands, failed states, foreign intervention, money, empire, oil, and the narcissistic heart of the West" (DeLillo 2011:113). The other as ghost from an ahistorical limbo, marginal being from a marginal failed state, hovering over the historical present like an apparition; the other as "virus" infiltrating the air; the other as a "presence that remain[s] unimaginable" (DeLillo 2011:65). In Falling Man, the realization that hell is the other figures at the center of the novel's spectral sensibility. Nowhere is this hauntological conception of the terrorist other as unbearable ghost in the air more creatively rendered than in Lianne's conflict with her neighbor about the oriental music that she cannot decipher and that, from her point of view, appears to be like the "uncanny

\footnotetext{
${ }^{16}$ Baudrillard uses similar metaphorics in his work on extreme phenomena-the "radical other" as "microbe" or evil as viral infection (1990:67-77, 88-94, 119 80)
} 
ghost" of an "echographical" sound virus that has come to haunt not only the building but also her own home (Wolfe 2008:85).

Ultimately, whether it is narrtivized by DeLillo in the form of apparition, virus, or echographical subtext, the spectral presence/absence of the terrorist in his novel persists as an "unpresentable" phenomenon in Lyotard's sense: an entity that marks a failure of the mind to clearly and directly represent or conceptualize that which is outside its frame of representation or conceptualization. In Falling Man, this incapacity to conceptually and verbally "figure out"17 the terrorist other goes hand in hand with certain defensive mechanisms of rejection that can be theorized in terms of Julia Kristeva's conception of the abject:

There is, in abjection, one of those violent and dark revolts of being against what threatens it and seems to emanate from an exorbitant outside or inside, cast beyond the possible, the tolerable, the thinkable. It lies there, quite close, but it is inassimilable. It implores, worries.... [The] abject, [a] discarded object, is radically excluded.... A weight of meaninglessness, about which there is nothing insignificant and which crushes me. On the border of non-existence and hallucination, of a reality that will annihilate me if I acknowledge it.... The disgrace of compromise, of the in-between, of treachery. $(1980 \mathrm{~b}: 9-10)^{18}$

“'Do I know what to call these people?'” (DeLillo 2011:64). In DeLillo's novel, the incapacity to name or conceptualize the evil motives behind the terrorist act, ${ }^{19}$ to attribute them to an identifiable chain of causation (political, social, psychological), forms a wall of abjection against which all discourse flounders, including the discourse that expresses rage and deconstruction of the other through verbal violence (name calling). Accordingly, the terrorist other eventually comes to represent an unmappable

\footnotetext{
${ }^{17}$ See Goux's reflections on the "non-figurable" (1978:18-9, 65-99).

${ }^{18}$ The above quoted excerpt is my translation. See also Kristeva on "asymbolicity" and the practice of postmodern literary experimentation with extreme phenomena as "an 'experience of limits"' (1980a:138-39).

${ }^{19}$ In Baudrillard's reflections on terrorism as a form of "radical otherness," the in-between of the terrorist's abjection, its philosophical inconceivability, does not so much stem from the latter's incomprehensible motives as from the limits of Western representations in naming those motives-the positing of the terrorist's intentions as a source of horror that is quite literally unthinkable (1990:88-92).
}

exteriority in relation to conventional thought and imagination-an indefinable "outside someplace"” (DeLillo 2011:64) that is "beyond the possible, the tolerable, the thinkable" (Kristeva 1980b:9). ${ }^{20}$ Even as she struggles with Alzheimer's, Anna C., one of the patients in Lianne's workshop, acknowledges the aporetic nature of trying to name the abject: when one cannot find a discursive place for such destructive negativity within an ordinary frame of reference, one is simply left with silence. The terrorist's fundamental motivation is so deeply rooted in negation and exclusion of the other that one fails to conceptualize and express his position in terms of difference, radical dissent, or even anarchy. However, even while she acknowledges her failure to conceptualize the terrorist, to include him within the realm of the verbally expressible (including the negative verbalization of name calling), Anna $C$. still manages to find a deeply therapeutic channel for her ineffable grief, her sense of grievance at the terrorists' transformation of one of the most significant instruments of communication between human beings (an airplane) into one of the deadliest weapons of negation of the other. Trying to "think'" (conceptualize) or name the abject motives of an individual who has espoused such deadly negation as a world vision and prime existential directive is "way too big,"' she argues, it is "'outside"” the realm of the conceivable and the expressible (DeLillo 2011:64); ${ }^{21}$ it is unspeakably abject:

"But this, what happened, it's way too big, it's outside someplace, on the other side of the world. You can't get to these people or even see them in their pictures in the paper. You can see their faces but what does it mean? Means nothing to call them names. I'm a name-caller from before I was born. Do I know what to call these people?... [Y]ou can kill [a] person in your mind a thousand times ... you could think it, you could see it in your mind and get some trade-off from that. But here, with these people, you can't even think it. You don't know what to do. Because they're a million miles outside your life. Which, besides, they're dead." (DeLillo 2011:64)

\footnotetext{
${ }^{20} \mathrm{Cf}$. Michel de Certeau's theorization of the status of the ethnic other as a "text-off' within the discourse of Western historiography (1992:1-55, 209-68; 249). See also Certeau's reflections on the "absent" other of history (1973:171$80)$.

${ }^{21}$ For Baudrillard, it is the terrorist's radical negation of the other that makes him "unintelligible" and, by the same token, a "radical other" (1990:89).
} 
It is perhaps precisely as an attempt to conceptualize and map the mind of the terrorist other that DeLillo undertakes his riskiest narrative experiment in Falling Man: a foray into the minds of the terrorists in their sleeper phase, as they train and prepare for the attacks; a dissection of the minds of men who have espoused death totally-as an existential purpose, as a mode of self-expression, and as the highest instrument of spiritual elevation. An attempt, then, to map the extreme territory of an "outside" of Western society-a realm dominated by ideas that represent the diametrical opposite of the affirmative foundation of Western postmodernity: men who posit the will to selfannihilation as a life motive-an existential finality so deeply internalized and affirmed that it becomes a religion in its own right.

In exploring the world vision and psychological makeup of his fictional terrorists, DeLillo makes it possible for the reader to learn a significant lesson about the power of Nietzschean ressentiment: its capacity to pervade every level of experience with a form of negativity that is all the more insidious for being potently life-validating as a form of self-surpassing-an illusory force that allows the terrorist to transcend his powerless humanity and project a fantasized image of himself that is far more positive than the hated other, far more positive than the life of helplessness that he seeks to supersede through self-sacrifice. ${ }^{22}$ The most important philosophical element that emerges from DeLillo's exploration of the radically negative consciousness of the terrorist is the deep homology between a nihilism that has evolved into an allconsuming world vision (" $[\mathrm{t}] \mathrm{here}$ is no purpose" to/in life other than "shock and death") and the terrorists' egotistical reduction of Americans to the nothingness of "empty space" (DeLillo 2011:177). In a moment of Sadean negation of the other as sovereign human being (Blanchot 1953), Hammad sums up the terrorist's objectification of Americans through a vision that is so radically exclusive of any sense of humanity that the future victims are perceived as "invisible" beings from the outset-immaterial ghosts whose lives are seen as devoid of meaning and finality, deprived as they are of the martyr's "love [of] death" (DeLillo 2011:177), the only higher knowledge that matters:

Hammad pushed a cart through the supermarket. He was invisible to these

\footnotetext{
${ }^{22}$ See Rashmi Singh on terrorism and the psychology of self-sacrifice (2011:10$17,75-118)$.
}

people and they were becoming invisible to him. He looked at women sometimes, yes, the girl at the checkout named Meg or Peg. He knew things she could never in ten lifetimes begin to imagine. (DeLillo 2011:171)

Keeping in mind Blanchot's remarks on the radical "egotism" and "absolute solitude" of the Sadean self as "Unique Being" (1953:690, 706 passim), the nihilism that we observe in DeLillo's terrorists is discernible through Hammad's self-definition as unique and "chosen" in comparison to the fantasized invisibility and lack of knowledge of the other (DeLillo 2011:174). Hammad finds a justification for his perfidious life and his horrid choices through this form of distinction and uniqueness that he affirms against and in negation of the depth and specificity of other human beings. Affirming the self and its higher purpose by relegating the other to the realm of invisibility: that this nihilistic self-affirmation through ontological voiding of the other is rooted in negation of life as a whole becomes increasingly evident in DeLillo's analysis of the mind of the terrorist as the author focuses on one key premise of the terrorist's destructive world vision: the principle that "death is stronger than life" and that the ultimate life purpose of the terrorist as unique being is to rise above a purposeless world in order to "close the distance to God" and achieve unity with God through an act that allows him to transcend his humanity(DeLillo 2011:172). A radical Aufhebung of any form of worldly attachment and in the process a radical negation of the substance of one's connection with humankind: there cannot be a more definitive nor more egotistical form of self-distancing from humanity than the positing of the terrorist's self as unique and chosen in its connection to the essence of the divine, in its unbridgeable superiority to the rest of humanity. Ultimate expression of negativity, the terrorist's urge to transcend his humanity by leaving it behind him is a radical form of resentment toward and denial of one's links to humanity-a twofold process that results in a negation of all ties to the world of material experience and a projection of the self entirely within the realm of transcendence that death will usher in. The terrorist's quest for oneness with God is born in his utter hatred of and contempt for the one thing that connects him to the rest of humanity: life as we know it, which, in the terrorist's vision, becomes illusory as "dust" and empty of meaning and worthy purpose (DeLillo 2011:174).

In a moment of great analytical insight, DeLillo manages to demonstrate how easy it is to mistake the 
terrorist's destructive, nihilistic rage against life for mystical ascesis (Martín Salván 2010:148 ff.) and quietist relinquishment of the incessant temptations imposed by our consumption-and-status-obsessed societies:

One man on a visit did not know the name of the town they were in, outside another town called Venice. He'd forgotten the name or had never learned it. Hammad thought it didn't matter. Nokomis. What does it matter? Let these things fade into dust. Leave these things behind even as we sleep and eat here. All dust. Cars, houses, people. This is all a particle of dust in the fire and light of the days to come. (DeLillo 2011:174)

Reduction to dust of the world in which we live: this is the core driving force behind the credo of the terrorist expressed in metaphoric form. Seen through Hammad's stream of consciousness, a key aspect of the terrorist's intransigent mind is predetermined by this radical devaluation of the world: in order for the terrorist to do what he has resolved to do, he must give up trying to discern any sense of meaning and worth in our worldly existence, having chosen to exit life. The pseudo-ascetic self-neglect and negation of self-image that the terrorists undergo before their crime is a dramatic indication of their nihilistic acceptance that nothing matters-not even a fresh set of clothes and a clean body-in a purposeless world that is soon to be left behind:

He sat in a barber chair and looked in the mirror. He was not here, it was not him.... He wore the same shirt and trousers every day into the following week and underwear as well ... clean or dirty didn't matter.... The radio plays news, weather, sports and traffic. Hammad does not listen. He is thinking again, looking past the mirror, which is not his, and waiting for the day to come, clear skies, light winds, when there is nothing left to think about. (DeLillo 2011:175, 178)

This form of nihilism represents a negation of self and world and otherness so inhuman that it requires a strong moral force to bolster its devastating power: religious righteousness, or the positing of the terrorist's life choices in radical opposition to the supposed faithlessness of the non-Muslims, the people who end up condemned en masse as dwelling in kufr (unbelief):
Here they were in the midst of unbelief, in the bloodstream of the kufr. They felt things together, he and his brothers. They felt the claim of danger and isolation.... There was the claim of fate, that they were born to this. There was the claim of being chosen.... There was the statement that death made, the strongest claim of all, the highest jihad. (DeLillo 2011:174)

Here, predestination is presented as the ultimate comfort of the man driven by ressentiment: a being so powerless facing a world in which he perceives no sense or solution; so utterly egoless that he chooses to surrender his freedom to a higher authority that scripts his existence and fates him for a sacrifice that will become the ultimate expression of his distinction: splitting the universal bond that ties him to humanity, the bond of life. Besides this urge to forgo the sense of autonomy that defines our humanness for the sake of a fantasized transcendent self predestined and moved by a higher force, there is, paradoxically, another equally important driving force that impels the terrorist: the selfvalidating fantasy of election projected by the ego of the unique being - a delusional definition of the martyr as a rare individual chosen by divine fiat, invested with the power to appropriate the other's life, to use the other as a pre-text in the narrative of his union with God:

But does a man have to kill himself in order to count for something, be someone, find the way?

Hammad thought about this. He recalled what Amir had said....

Amir spoke in his face.

The end of our life is predetermined. We are carried toward that day from the minute we are born.... This is not suicide in any meaning or interpretation of the word. It is only something long written. We are finding the way already chosen for us....

But what about this, Hammad thought. Never mind the man who takes his own life in this situation. What about the lives of the others he takes with him?...

Amir said simply there are no others. The others exist only to the degree that they fill 
the role we have designed for them. This is their function as others. Those who will die have no claim to their lives outside the useful fact of their dying.

Hammad was impressed by this. It sounded like philosophy. (DeLillo 2011: 175-76)

While DeLillo's detailed focus on the thought processes of the $9 / 11$ terrorists indicates the substantial attention he devotes to analyzing the psychological motivations of the members of the terrorist cell, the author literally goes out of his way (narratively speaking) to emphasize the fact that the harsh realities of terrorism and its work of violent systemic subversion are not specific to radical Islamism. Hence the relatively lengthy parenthetical excursion into Martin's past-his former life as Ernst Hechinger. In a deft twist of plot, the author turns our readerly expectations upside down by confronting us with the dark side of Martin's life: his past involvement with left-wing anarchism and terrorism-radical and subversive European-bred movements that arose in reaction to the complexification and global ramification of late capitalism. Through DeLillo's exploration of Martin's somber past, we become acquainted with a certain type of European leftist groups that saw no way of dealing with the increasing ramification and global reach of capitalism except through terrorist action. In a horrifying moment that represents a strange mix of confession, revelation, and tawdry provocation, Martin seems to reconnect with his terrorist past as a possible sleeper cell member and funder of terrorist activity, revealing a deeply shocking vision of the twin towers as the natural accursed share ${ }^{23}$ in a capitalist system that has, according to him, grown excessively powerful and overweeningly fond of displaying its power. In his highly irresponsible and hateful take on the destruction of the twin towers, the art dealer suddenly reveals his dark side by interpreting the World Trade Center as a sacrificial object in the most primitive sense:

\footnotetext{
${ }^{23}$ Martin Ridnour's Faustian position and the unspeakable anarchism and ruthlessness that it presupposes is evocative of Georges Bataille's conception of the accursed share (1967:95 passim). In Bataille's theory, the dynamic of the accursed share is based on a form of antiutilitarian "destruction whose essence is to consume without profit that which might remain in the bondage of useful deeds.... The [object of destructive consumption] is a surplus taken from the mass of useful wealth. And it can only be withdrawn in order to be consumed without profit.... It is the accursed share from the moment it is chosen.... But its curse wrests it from the [commodified] order of things" (1967:95-97; my translation). See Derrida's analysis of Bataillian economy (1967:373-407) and Jean-Joseph Goux's critique (1990) of both Bataille's accursed share and Baudrillard's conception of a symbolic economy based on "fundamental negation of value" $(1976: 256-68 ; 262)$ as it is defined in the market economy.
}

"But that's why you built the towers, isn't it? Weren't the towers built as fantasies of wealth and power that would one day become fantasies of destruction? You build a thing like that so you can see it come down. The provocation is obvious. What other reason would there be to go so high and then double it, do it twice? It's a fantasy, so why not do it twice? You are saying, Here it is, bring it down." (DeLillo 2011:116)

As if leaving us to contemplate the causes and consequences of these dreadful words, DeLillo inserts an implicit ellipsis at this point in the novel. This is then how the author decides to structure the mystifying retrospective sections on Martin as Ernst Hechinger: a ruthless statement followed by a long elliptical gap, then resumption, twenty-eight pages later, of the dissection of a ressentiment-driven man who once chose (or was closely involved with) terrorist subversion as a belief system and as a form of social action. As this unexpected cloud of suspicion begins to hover over Martin, DeLillo indirectly and effectively uses his past to deconstruct recent myths developed around the figure of the Middle Eastern other as a "naturally" subversive presence within Western societies-radically opposed to their way of life, inherently inimical to their interests. ${ }^{24}$ What DeLillo teaches us through this exploration of Martin's dreadful past is that "the enemy within" can come from any quarter, that subversive anti-systemic movements in Western societies do not have any specific ethnic or religious coloration. One significant conclusion can be made based on this dark chapter in Martin's life. DeLillo's retrospective parenthesis appears to be a cryptic attempt on the author's part to debunk negative fantasies about the Middle Eastern other as essentially antithetical to Western postmodernity and the increasing levels of socioeconomic complexity that it presents. In exploring the European terrorist's radical rejection of that complexity, DeLillo not only manages to generalize the problematic of terrorism as extremist dissent by taking it beyond the sphere of the Middle Eastern other, he also manages to confront us with the broader ethical question of trust: the vital necessity in our increasingly diversified and interrelated global system to learn to trust the other without fully knowing

\footnotetext{
${ }^{24}$ See DeLillo's position on the question of Middle Eastern otherness (2001:34 ff.). See also Marie-Christine Leps's elaboration on DeLillo's position (2010:188-90)
} 
her/him—to accept, in other words, to assert the salutary primacy of trust in the Luhmannian sense (Luhmann 2014) as well as in the sense of the "enlightened catastrophism" theorized by Jean-Pierre Dupuy (2002). Based on Nina's assessment of her relationship with Martin, it is sometimes even healthier not to know the other fully even as we decide to trust them, adopting a carefree attitude and accepting to live side by side with them. In this sense, the excursion into Martin's former life as Ernst Hechinger is a particularly apt narrative device through which DeLillo seeks to deconstruct pathological fears of the Middle Eastern other even while attempting to emphasize the radical otherness and opacity of every human being-a measure of the depth and complexity of human psychology and motivation:

"All these years. Never forcing the issue. Look at the man he's become, the man we know. Isn't this the kind of man they [his wealthy clients] would have seen as the enemy? Those men and women on the wanted poster. Kidnap the bastard. Burn his paintings."

"Oh I think he knows this. Don't you think he knows this?"

"But what do you know? Don't you pay a price for not knowing?"

"It's my price. Shut up," her mother said. (DeLillo 2011:148)

Laying aside the question of trust, let us keep in mind that what we get to know through the Ernst Hechinger parenthesis is quite pertinent to the narrative status of Falling Man as a profoundly analytical, nearly clinical document: the novel's status, in other words, as an almost Fryean anatomy (Frye 1957) - a carefully subdivided multipartite exploration of the intersubjective social terrain on which extreme phenomena emerge and a multilayered examination of the traumatic effects that accompany such phenomena as well as the potentials for healing. Thus, what we witness in the odd dialogic confrontation between mother and daughter is more than an attempt to deal with the tangled ethics involved in a complex relationship. Lianne's strange conversation with Nina ends up being a sort of taxonomy of the extremist mind that presents us with interesting elements of structural and ideological isomorphism between the leftist sleeper cell and the jihadist one. Through Nina's revelations, we learn that both radical structures are driven by universalistic and unitary ideological visions that are theorized by a group of influential demagogues:

"He thinks these people, these jihadists, he thinks they have something in common with the radicals of the sixties and seventies. He thinks they're all part of the same classical pattern. They have their theorists. They have their visions of world brotherhood.... He's here, there and everywhere."

"Operating under a false name," Lianne said. (DeLillo 2011:147)

Universalism and a sense of a unified solemn mission determined by a historical context that leaves the terrorist no choice but to assume his historical position: the leftist extremists, according to Martin, are similar to the jihadists in that they were guided by a similar conception of a greater historical calling projected globally, a grand emancipatory narrative (Lyotard 1985:xxiii-xxv): "What was [Martin] waiting for?'" Lianne asks her mother-a question charged with symbolism (DeLillo 2011:146). "'History,"' her mother replies, "[t]he call to action"” (DeLillo 2011:146). Along with the sense of being guided by a historically predestined cause that must exteriorize and actualize itself on a universal scale, what emerges from Nina's account is another interesting aspect of the extremist mind that I have associated with Nietzschean ressentiment: it is that nihilistic urge that finds its origin in the oppositional negation with which the extremist faces the world of otherness and difference alike-a reduction of the immense diversity of the Western World to an illusory consumerist wasteland that must be resisted through a radical attitude of "renouncing":

"Do they [the jihadists] make him nostalgic?"

"Don't think I won't bring this up."

"Bare walls. Nearly bare, you said. Is this part of the old longing? Days and nights in seclusion, hiding out somewhere, renouncing every trace of material comfort. Maybe he killed someone." (DeLillo 2011:147)

The European radical's elated feeling of a unique historical mission, of an egoless self-surpassing through the mission, culminates in the same sense of 
pseudo-ascetic detachment from the world that is characteristic of the jihadist. Despite the jittery disjunctions of the conversation between mother and daughter, what the exchange reveals on the metanarrative level is DeLillo's complex analytical approach as he seeks to shed light on another aspect of Islamist extremism: the fact that the radical disaffiliation from society chosen by the jihadist might ultimately be a form of "anti-modern nihilism" originating in a sense of deep alienation from postmodern capitalism both as a socioeconomic system and as a world vision (Zafirovski and Rodeheaver 2013:355). As is obvious from Keith's firsthand experience with collective death and the disorders it has engendered in him, the hopeless intransigence and deep virulence of the Islamists' antimodernist militancy is not only a highly dangerous form of social disaffiliation, it is also a profoundly pathogenic force with devastating effects on the individual who becomes exposed to it. It is to this question-the deeply pathological aspects of grief caused by terrorist action-that I will now turn.

\section{Trauma, Temporality, and the Three Imperatives of the Wounded Consciousness}

As argued earlier, Keith's reaction of revulsion facing death and destruction near Ground Zero marks the beginning of a complex posttraumatic ailment: his adoption of a mechanism of self-protective denial, the central element in what may be described as an unavowed strategy of flight and self-induced amnesia. As we follow the protagonist through his brief affair with Florence Givens, we come to observe a significant difference between the two characters: while Florence is active and emotional, dealing with her traumatic experience through retrospective narration, Keith remains withdrawn from the event and from those among his friends who survived it; his cognitive experience of the quotidian in his home and outside is marked by a sense of derealization and affective disengagement. As his wife rightly observes, besides suffering from PTSD, Keith is also plagued by a complex combination of grief and survivor guilt that manifests most painfully in his refusal to accept the fact that he is alive and that the city is still alive and whole and safe from the destruction he has witnessed. With various aspects of his daily life feeling "familiar but mean[ing] nothing to him" (DeLillo 2011:66) Keith finds himself increasingly withdrawn from New York City, both affectively and cognitively:
He noticed things, all the small lost strokes of a day or a minute, how he licked his thumb and used it to lift a bread crumb off the plate and put it idly in his mouth. Only it wasn't so idle anymore. Nothing seemed familiar, being here, in a family again, and he felt strange to himself, or always had, but it was different now because he was watching. (DeLillo 2011:65)

Quite expectedly, this uncanny experience of a derealized daily experience results in Keith's failure to use the cleansing flow of time in order to come to terms with the burden of the past and project himself into a safe and protected world in the future: that past is, tragically, "still close to [him].... Not like something happening yesterday but something always happening ... always in the air" (DeLillo 2011:78). With Eliot's dictum in mind-"If all time is eternally present/All time is unredeemable" (1971:175)—we could argue that Keith's decision to partly relocate to Las Vegas may possibly be a subterfuge that marks his unconscious desire to evade the nightmare of history (the constant presentness of the past) by cultivating a form of staged disappearance through sheer speed and movement, as if this lifestyle shift is a way for the tormented man to come to terms with his ephemerality by representing his own disappearance to himself in a cyclical manner. As far as this particular aspect of Keith's denial is concerned, Lianne's healthy confrontation, painful as it is, represents an apt pronouncement on her husband's ailment and the unavowed nature of its stratagems and entanglements:

"But I know what's happening. You're going to drift away. I'm prepared for that. You'll stay away longer, drift off somewhere. I know what you want. It's not exactly a wish to disappear. It's the thing that leads to that. Disappearing is the consequence. Or maybe it's the punishment."

\section{$[\ldots]$}

There was one final thing, too self-evident to need saying. She wanted to be safe in the world and he did not. (DeLillo 2011:214, 216)

Here, Lianne's interpretation of the twofold process at work in Keith's new lifestyle choice-denial of the past through relocation to Las Vegas and an 
unconscious wish to disappear like the other victimsis strongly evocative of Freud's description of the processes involved in the management of trauma through anticipatory scenarios:

Now it is an important advance in selfprotection when [a] traumatic situation of helplessness is not merely awaited but is foreseen, anticipated.... I anticipate that a situation of helplessness will come about... I will anticipate this trauma; I will act as if it were already present.... The ego, which has experienced the trauma passively, now actively repeats an attenuated reproduction of it with the idea of taking into its own hands the directing of its course. (1936:112)

As we witness the unfolding of the marginal relationship between the two survivors of the tragedy, Florence and Keith, we soon realize that their struggle with trauma is expressed in terms of a symptomatic "mark" from the past-a traumatic wound that interferes with their daily lives(DeLillo 2011:89). In their attempt to come to terms with the mark together, Keith and his lover find themselves engaged in a different type of hauntological scrutiny in which the ghost that haunts memory and perception is not the presence of the terrorist but the difficult-to-trace residue of traumatic content that invades the mind from conscious or unconscious sources, destabilizing perception and the sense making faculties like a virus, interfering with wellbeing and the capacity to affirm the beauty of life. In this process of deciphering the intangible mark of trauma that haunts him from the past, Keith relies on Florence's narrative in order to recover the experience to which he refuses to return, "noting every detail" of her retrospective contemplations, "trying to find himself" through her words but always failing to participate with his own narrative of that fateful day (DeLillo 2011:59). Like the victims of Alzheimer's, Florence is trying to come to terms with the sense of "loss" and "diminishing returns" that the status of survivor has introduced into her life, obliging her to reflect on the possibility of accepting her condition by acknowledging "how small we are"” and by "put[ting] it in God's hands"':

There was an element in Florence that was always close to some emotional distress, a memory of bearing injury or sustaining loss, possibly lifelong, and the laughter was a kind of shedding, a physical deliverance from old woe, dead skin, if only for a moment.... She talked about the tower, going over it again, claustrophobically ... it was inside them now ... he needed to hear what he'd lost in the tracings of memory. This was their pitch of delirium, the dazed reality they'd shared in stairwells. (DeLillo 2011:60, 9091)

To relinquish one's capacity to analyze and anticipate the effects of trauma is, in some regards at least, similar to the process of accepting the diminishment of mental faculties that an Alzheimer's patient has to endure. Unlike Florence and the passive fatalism that enters into her life after the tragedy, Keith adopts a more insidious form of passivity, one that is indicative of a tendency toward escapism and withdrawal from the task of tackling both the traumatic event and his own reaction to it. As we witness Keith's marginal, dazed existence in New York after the tragedy, it is impossible for us as readers not to empathize with his decision to partially relocate to Las Vegas in order to avoid facing the burden of both private and collective history in New York. Keith's refusal to go through the grief process and consciously engage his trauma is, in many ways, a form of selfprotective numbing against the hazards of tackling the complexities and intricacies inherent in processing the past as a whole. For in Falling Man, memory presents itself not only as a component of identity that is marked by deteriorations and traumatic losses, but also as a deeply unsettling, deeply emotional locus of fundamental, unavowed grief. As Dr. Apter puts it, memory is the shifting field of a gradual "loss," of a progressive dynamic of degeneration and "diminishing returns" that forces one to confront one's human frailty and accept the "delicate" nature of remembrance itself, acknowledging the fallibility of one's faculty to recollect and process and make sense:

Lianne learned this from Dr. Apter the day after it happened. She'd seen the slow warning, over months. Rosellen still laughed at times, irony intact, a small woman of delicate features and chestnut skin. They approached what was impending, each of them, with a little space remaining, at this point, to stand and watch it happen. (DeLillo 2011:60, 94)

She [Lianne] thought of the conversation with Dr. Apter concerning the day when Rosellen could not remember where she 
lived. This was an occasion that haunted Lianne, the breathless moment when things fall away, streets, names ... all sense of direction and location, every fixed grid of memory. (DeLillo 2011:156)

In some ways, accepting, sometimes, to put our sense-making faculties in abeyance is not necessarily a nihilistic surrender to senselessness, as Rosellen's choice to seek refuge in her church eloquently illustrates; instead, it can be a saving act of faith through which we acknowledge our incapacity to attribute meaning to every event in our existence, a salutary admission that some events are simply too complex and undecidable to be controlled by our sense-making faculties. Understandably, Keith does not seem to be able to reflect on the link between memory and the importance of accepting the fact that existence itself is an ongoing loss and a winding down; instead, his confrontation with the gaps of his memory and sense-making faculties is always marked by effects of estrangement followed by denial, as in the unsettling moment when he fails to make sense of the woman on horseback in the park:

.... [l]t was strange, what he was seeing down by the community garden and coming toward him, a woman ... on horseback ... it took him a long moment to understand that horse and rider had come out of a stable somewhere nearby....

It was something that belonged to another landscape, something inserted, a conjuring that resembled for the briefest second some half-seen image only half believed in the seeing, when the witness wonders what has happened to the meaning of things, to tree, street, stone, wind, simple words lost in the falling ash.

(DeLillo 2011:103)

It is important to bear in mind, in this context, the implicit connection between Keith's refusal to deal with these moments of cognitive disconnect that he experiences and the Alzheimer's patients' own struggles with sense and narrative structure. The connection between the erasures and losses of Alzheimer's and Keith's traumatized associations in the park is perhaps difficult to discern; but it is also highly significant from an interpretive point of view. Indeed, Falling Man makes it amply clear that both traumatic occurrences lead to a defamiliarization of "the meaning of things" and, ultimately, its disappearance "in the falling ash" as material objects gradually evolve from signifying entities to things in themselves(DeLillo 2011:103). Keeping in mind the centrality of Alzheimer's and the esthetic of disappearance in DeLillo's novel, it is equally important to point out the author's shift from the subjective to the collective in such contexts: in moments of cognitive disconnect such as Keith's experience in the park, the sudden eruption of $9 / 11$ imagery (falling ash) forces the reader to engage the significance of Falling Man as the record of a traumatic disruption that goes beyond the struggles of one man-a universal shock that has resulted in nothing less than the deconstruction of the "fixed grid" of collective memory. In choosing to face traumatic disruption with denial and silent pain, "even the deepest moan" uttered by the victim "may not be grief but only moan" (DeLillo 2011:156). As far as Keith is concerned, his failure to take his trauma from inner disconnect to moan to structured grief leads to escapism: his attempt to consign the struggles of his consciousness to oblivion by choosing partial relocation to Las Vegas.

Keith in Las Vegas: one of the first things that we notice about his new life is the fact that his refusal to remember and talk about the trauma is mirrored by Chang's own denial. Ultimately, Keith starts to avoid seeing Chang altogether and with this second refusal any hope of processing his trauma within a temporally coherent retrospective narrative vanishes-any deliberate relation to the past: "He was avoiding Terry Chang. He didn't want to talk to him, or listen" (DeLillo 2011:227). Keeping in mind this shift in Keith's strategy of denial toward more active refusal of the past and its marks, Las Vegas becomes, in a way, the ideal choice for a man who seeks to flee his trauma rather than confront it. DeLillo makes it quite evident that the setting deliberately chosen by his protagonist is posthistorical, without any trace of the potential ethnic and cultural frictions that New York City presents-a setting, in short, where Keith is capable of feeling that "purged sensation" of detachment from the nightmare of history, achieving a radical "invalidation" of the impinging force of time:

He was fitting into something that was made to his shape. He was never more himself than in these rooms, with a dealer crying out a vacancy at table seventeen. He was looking at pocket tens, waiting for the turn. These were the times when there was nothing outside, no flash of history or 
memory that he might unknowingly summon in the routine run of cards.... In the off-hours he talked to dealers at empty blackjack tables ... waiting in some zone of purged sensation.... The point was one of invalidation. Nothing else pertained. Only this had binding force. (DeLillo 2011:225, 230)

Furthermore, the world in which Keith pursues his new job is decidedly diverse and transnational, just like New York; but it has the added benefit of being a friction-free transnational environment in which people are united mainly by wealth and by the ultimate agent of self-induced amnesia: gaming. Still, while it is tempting to assume that what Keith is seeking in this insulated transnational universe of gambling is some form of ecstatic, mind-numbing drug to help him lose himself in the realm of chance, what obtains in his selfanalytical reflections is the diametrical opposite of ecstatic loss of self. Through poker, he seems to seek precisely the opposite: what he was dispossessed of in the building where so many of his fellow humans perished, namely, a capacity to anticipate and control certain aspects of random occurrence, what Roger Caillois terms Alea in his theory of games-the chance factor (1967:47 ff.):

There were times in the sports book when he glanced at one of the screens and wasn't sure whether he was seeing a fragment of live action or of slow-motion replay. It was a lapse that should have unsettled him, an issue of basic brain function, one reality versus another, but it all seemed a matter of false distinctions, fast slow, now, then, and he drank his beer and listened to the mingled sounds....

He showed his money in the poker room. The cards fell randomly, no assignable cause, but he remained the agent of free choice. Luck, chance, no one knew what these things were. These things were only assumed to affect events. He had memory, judgment, the ability to decide what is true, what is alleged, when to strike, when to fade. He had a measure of calm, of calculated isolation, and there was a certain logic he might draw on.... [T] he game had structure, guiding principles, sweet and easy interludes of dream logic when the player knows that the card he needs is the card that's sure to fall. Then, always, in the crucial instant ever repeated hand after hand, the choice of yes or no. Call or raise, call or fold, the little binary pulse located behind the eyes, the choice that reminds you who you are. It belonged to him, this yes or no, not to a horse running in the mud somewhere in New Jersey....

These were the days after and now the years, a thousand heaving dreams, the trapped man, the fixed limbs, the dream of paralysis, the gasping man, the dream of asphyxiation, the dream of helplessness.

A fresh deck rose to the tabletop.

Fortune favors the brave. (DeLillo 2011:211-12, 230-31)

Positing a premise diametrically opposed to Mallarmé's "A throw of the dice will never abolish chance" (1914), Keith seems to be able to integrate the hazards and contingencies of chance within a structured mental framework controlled by him, despite the obvious "basic brain function" disconnects of the hyperreal hall of mirrors that his new setting represents (DeLillo 2011:211). That this new setting is, however, inherently escapist, like an illusory chimera, is obvious even to Keith when, in a rare moment of analytical contemplation, he finds himself reflecting on the hyperreality of his new urban environment:

He rented a car and took a drive in the desert, starting back after dark and then climbing a rise and leveling out. It took him a moment to understand what he was looking at, many miles ahead, the city floating on the night, a feverish sprawl of light so quick and inexplicable it seemed a kind of delirium. He wondered why he'd never thought of himself in the middle of such a thing, living there more or less. He lived in rooms, that's why. He lived and worked in this room and that. He moved only marginally ... and he hadn't known until now, looking at that vast band of trembling desert neon, how strange a life he was living. (DeLillo 2011:226-27)

Despite this vague demur at his choice, Keith seems to find a measure of inner peace in the 
"delirium" that Las Vegas represents-a Baudrillardian hyperreal delirium, but also a specifically post-historical one (Baudrillard 1981:9-68; 1986:39 ff.); for Las Vegas, in Keith's unconscious, is the ultimate alternative to New York in that it is defined by one significant characteristic: its apparent capacity to exist beyond the dialectical shocks of history, as a city from which any potential clash of civilizations has been removed; a post-historical, post-dialectical "zone of purged sensation" with "no flash of history or memory," where the ethnic and cultural diversity of the world seems to be peacefully united under the neutral medium of money (DeLillo 2011:226, 225, 230).

Compared to her husband, Lianne chooses to assert a quite different urge-that for self-preservation and healing: the need to feel "safe in the world" that New York is and the need to confront the source of her pain (DeLillo 2011:214), no matter how irrational or jarring the confrontation (the right remembering). Keith's wife deals with her fears and trauma at first in strife and suffering, but she gradually manages to make her way toward a more methodic and constructive process in the work of mourning. Eventually, she becomes driven by the deeply anchored, unyielding imperatives of remembrance and a healthy acceptance of the past through recollection in order to learn to live with the tragedy, if not make sense of it. In the early phases of grieving, she struggles with her neighbor's choice to listen to oriental music, a choice that is invested with deep symbolic significance, since the oriental music becomes, in Lianne's imagination, a presence as sinister as the ghost of Bill Lawton-another spectral manifestation of the other; a liminal presence/absence that haunts the stairs and corridors of Lianne's building and sets her in search of some form of meaning within a floating zone of seeming chaotic noise that denies her all meaning and becomes torture for her. In this highly sensitive context, the music played by Lianne's neighbor also puts her in an uncomfortable zone of extreme intellectual indeterminacy in which "Everything seemed to mean something" (DeLillo 2011:67). As her traumatized mind scans the reality around her for signs of meaning and pattern, Lianne realizes that "the noise in her head" has merged with the "music [as] noise" and pain in order to form a spectral entity that keeps haunting her nights with unsettling thoughts (DeLillo 2011:67). Like the children searching the skies for signs of Bill Lawton, Lianne finds herself trying to fathom the meaning of the music and the motive behind her neighbor's choice. At this point, it is important to specify that while the oriental music is evidently the focal point of a deeply negative fantasy in which the foreign sounds are invested with traumatic overtones very much akin to the negative associations projected by Justin Neudecker and his friends, Lianne manages to transform this kernel of negativity into an affirmative force that helps her confront the residual ghost of the oriental other within her. Besides, Lianne's negative feelings make it possible for her to accept her anger and helplessness and to consider ways to exteriorize them by expressing and sharing them in the form of grievance. Rendered in the fluid, slightly disjunctive form of DeLillo's often experimental stream of consciousness technique, Lianne's repetitive reflections on the haunting music are particularly telling:

They lived on the top floor of a redbrick building, four-storied, and often now, these past days, she walked down the stairs and heard a certain kind of music, wailing music, lutes and tambourines and chanting voices sometimes, coming from the apartment on the second floor, the same CD, she thought, over and over, and it was beginning to make her angry....

A woman named Elena lived in that apartment. Maybe Elena was Greek, she thought. But the music wasn't Greek. She was hearing another set of traditions, Middle Eastern, North African, Bedouin songs perhaps or Sufi dances, music located in Islamic tradition, and she thought of knocking on the door and saying something. (DeLillo 2011:67)

Counterproductive as they are, Lianne's negative thoughts toward her neighbor drive her into staging a violent acting-out, which in turn makes it possible for her to realize the irrationality of her having projected so much evil intent on her neighbor and on the music she enjoys and firmly defends in the face of Lianne's protestations: "Lianne knew she was going crazy" (DeLillo 2011:120). Before she comes to that sane and self-critical conclusion, however, the agonizing ruminations with which she reacts to the music make it possible for her to begin to understand two significant facts about the associative and iterative nature of trauma: the fact that residual traces of a traumatic event can be activated within a person by association; and the fact that trauma repeats itself in unpredictable and debilitating ways, erupting in abrupt and violent 
fashion through imaginary triggers, such as the supposedly hostile music, or through real triggers, such as the confrontations with Falling Man.

Being linked with an entity that has now become a source of painful associations (the Middle East), the negatively connoted music has ceased to be a form of artistic expression or a means of enjoyment, looming in Lianne's mind as a painfully invasive force, one that she is no longer capable of limiting to the material space of the corridors and the staircase: the music has now taken the form of alien intruding "Thoughts from nowhere, elsewhere, someone else's"-an abject entity from "outside someplace, on the other side of the world" (DeLillo 2011:69, 64). The invasion of "someone else's" sound also becomes, by association, the abject, uncanny invasion of that someone else himself: the other is hell under any form, including by association; and with this sad equation becoming an increasingly painful presence in Lianne's mind, she quickly begins to find the music an excessive "surplus" that must be not only "disinvest[ed]," but also voided of cultural, esthetic, and even semantic content (Blanchot 1980:41). Accordingly, Lianne ends up relegating her neighbor's music to the realm of raw noise associated with violence and pain ("forced breathing" and "lament") rather than musical harmony-primal nature instead of refined culture, noise in itself ("noise as noise") instead of sound structured into significant "statement":

Do this. Knock on the door. Adopt a posture. Mention the noise as noise. Knock on the door, mention the noise, use the open pretense of civility and calm, the parody of fellow-tenant courtesy that every tenant sees as such, and gently mention the noise. But mention the noise only as noise. Knock on the door, mention the noise, adopt a posture of suave calm, openly phony, and do not allude to the underlying theme of a certain kind of music as a certain form of political and religious statement, now of all times. Work gradually into the language of aggrieved tenancy. Ask her if she rents or owns. (DeLillo 2011:69-70)

Negative and painful as they are, these thoughts and the confrontation that they culminate in help Lianne become aware of two major elements in the unfolding of the grief process: first, the importance of assuming the full negativity of her emotions in loss and sadness, including when that negativity consists in reducing a cultural artifact to unbearable "noise"; second, the importance of acting out on that pent up negativityfinding a peaceful, constructive stage for one's most painfully negative emotions in order to see them played out, exteriorized, and hopefully exorcized in the process of exteriorization. With the "noise" incident, as with her interpretation of the work of David Janiak later, Lianne discovers that the negative associations of the traumatized mind can be converted into a positive form of guided recollection, an active and self-controlled conjuring of the past: the right remembering.

Thus, it is through a similar process of conversion that Lianne finds herself struggling to transform the negative emotions that she associates with David Janiak into a motive force that empowers her to face him, literally and figuratively, after a series of confrontations that always began in spellbound fascination and an attempt to understand the message behind the medium, only to end in feelings of intense vulnerability followed by flight. As a first step, when Lianne finds herself engaged in retrospective analysis of these past encounters, trying to understand the artist's work through the mediation of technology, ${ }^{25}$ she manages to grasp the iterative nature of Falling Man's performance, identifying its teleological signification through a painstaking work of metonymic association. After a meticulous process of ratiocination, Lianne succeeds in establishing the connection between Falling Man's performance and a photograph of one of the $9 / 11$ victims falling to his death from the North Tower of the World Trade Center, acknowledging, with ruthless honesty, the contradictory emotions that she associates with the terrible picture:

It hit her hard when she first saw it, the day after, in the newspaper. The man headlong, the towers behind him.... Headlong, free fall, she thought, and this picture burned a hole in her mind and heart, dear God, he was a falling angel and his beauty was horrific. (DeLillo 2011:221-22)

This is the originary moment of horror, then; the recorded tragic gesture that Falling Man manages to invest with full anamnestic force ${ }^{26}$ : now that Lianne

\footnotetext{
${ }^{25}$ The technologically aided reconstruction process conducted by Lianne can be understood in terms of Jean-François Lyotard's concept of "telegraphy" (1991:47-57).

${ }^{26}$ Marie-Christine Leps proposes an incisive reading of the position chosen by Falling Man for his performance, which is based on a reproduction of the seventh photograph in the series of eleven taken by Richard Drew (2010:188).
} 
knows the primal referent behind the man's numbingly iterative performances, the latter begin to strike her as retrospective "composition[s]" strategically charged with a power of recall so intense that they are bound to leave the beholder powerless and spellbound before the "immensity" of what they represent (DeLillo 2011:222). As for the quasi-shamanic power wielded by Falling Man himself, it is devastatingly twofold: on an affective level, that power is derived from a deeply felt tragic event that is etched into the collective consciousness of Americans like an indelible mark; on another more cognitive level, Falling Man's capacity to affect people with great power stems from the generic, or archetypal, nature of the pictogram achieved through his performance, for the referent frozen in space-time by the artist represents an arrested variation on the "ideal falling motion of a body"-a universal, "nameless body" that stands as an emblem of humanity (DeLillo 2011:223, 222). Charged with metanarrative meaning, this moment of retrospective analysis and deep insight experienced by Lianne culminates in a revelation that allows us as readers to have access to another of those condensed symbolic associations that seem to be central to Falling Man's treatment of trauma and history, its clinical dissection of the correspondences between the collective pain brought about by the terrorist event and the microscopic inscriptions of that pain on the subjective level. The condensed symbol that Lianne evokes with Hemingwayan indirection and that seems to be brimming with hermetic meaning is that of the hanged man in the tarot deck-a mark of human consciousness thrown into a state of abeyance with the possibility, also, of acquiring unique wisdom and insight into the world through that state of abeyance. As the symbol of a form of being and temporality that are most hauntological indeed, the hanged man is the interstitial entity par excellence, emblematizing a state of suspension between two spheres of existence: the physical world and the spiritual world. Through his in-between position, the hanged man represents both inevitable sacrifice (of the ego, of material prosperity, among other things) and the possibility of contemplating life from a different perspective, focusing one's mind on the essential questions and gaining new insight into existence. Viewed from a philosophical perspective, the interstitial status of the hanged man (a being suspended between two worlds) may be interpreted as the position of an individual who is subjected to loss and immobility even while he is given the opportunity to philosophize about temporality and existence in ways that are not granted to those who dwell in the temporal rhythms of the quotidian and its material pursuits. ${ }^{27}$

Ultimately, we may ask at this point, is there a moral to be learned from the visual parable of David Janiak? What sense is to be made of the performance work of Falling Man as postmodern hanged man? Once again, a possible answer to the enigma of the Falling Man/hanged man performance lies in the reflections developed by Lianne during her investigation-starting with the first reflection, which contains perhaps the most striking revelation: her symbolic interpretation of Falling Man's "position ... in his suspended state" as a "trump card in a tarot deck" in spite of the fact that the card she imagines for Falling Man represents an upside-down "figure ... in a stormy night" (DeLillo 2011:221). Interpreting the upside-down position of a tarot figure suspended in a sort of dark night of the soul as a positive force marks, in my opinion, Lianne's intuitive admission that the perspective of the hanged man is perhaps what is required in order for the traumatized consciousness to reflect on the past in a pacified and self-empowering fashion. As with the oriental music incident, Lianne seems to realize, intuitively, that the apparent negativity of Falling Man's performance-the topsy-turvy chaos and the stormy night represented by his position-is also a "trump," a major resource to be used strategically. The apparent negative potentials of this unnatural, upside-down state can be converted into a form of pacified retrospective reflection on the fears and traumas of the past from a novel, creative, and compulsion-free perspective (the right remembering). Seeing things differently herself now, and even though she admits that Falling Man still "elude[s] her," she finds the necessary strength to endure the harsh logic of the artist, mustering enough equanimity and analytical clarity to remember his confrontational appearances constructively, processing the poisonous power of his work even while she attempts to distill from it the barely decipherable trace amounts of healing that he seeks to administer in his own hermetic way (DeLillo 2011:224). Unlike her traumatic street encounters with Falling Man, Lianne's rediscovery of the artist's revealed poisons and hidden antidotes is purely analytical, occurring within a setting entirely chosen and controlled by her: the room where she keeps her computer. Methodic retrospective

\footnotetext{
${ }^{27}$ On the connections between stillness/suspension and contemplation outside the temporal rhythms of the quotidian, see the analyses proposed by James Gourley (2013:2-5) and Julia Aptizsch (2010:97-101) in their readings of Falling Man's performance.
} 
research and reflection within the familiar space of her home allows the protagonist to transform shock into therapy and begin to come to terms with those jarring street confrontations in a constructive, healing manner. Here Lianne's capacity to distance herself from the subject of her inquiry is a far cry from her ambiguous reaction to Falling Man's actual performances: spellbound fascination followed by anxious flight. Thanks to her retrospective digital dissection of Falling Man's unsettling message (a call to remember our mortality), Lianne initiates a constructive remembrance of her anxieties, realizing in the process that return to a traumatic event does not have to be done in fear and vulnerable passivity. Through the mediation of technology and intellectual analysis, Lianne manages to accept (and be strengthened by) the message with which Falling Man seeks to confront New Yorkers even as they are frantically immersed in the hustle and bustle of life: the universality of death.

Therein resides the shocking power of Falling Man's toxic performances. His abrupt injunctions to pause and contemplate life from a different perspective in order to ponder the mortality of all humans is deeply intertwined with his conception of art as unmediated event, as the unmitigated shock of a raw confrontation with the fact of death-a conception of art as antidote, in sum, performance as pharmakon. As unmediated event and antidote, the type of performance art practiced by Falling Man is based on the power of pure visual impact beyond words or concepts, an unguided experience that leaves the beholder grappling with the performance as a thing in itself, trying to tease some meaning out of the event:

If [the] photograph [that presents him at work] was an element in his performances he said nothing about it when questioned by reporters after one of his arrests. He said nothing when asked whether anyone close to him had been lost in the attacks. He had no comments to make to the media on any subject.... He turned down invitations to speak at the Japan Society, the New York Public Library and cultural organizations in Europe. (DeLillo 2011:222)

Still, for all his rejection of any form of metacommentary, the man who "had no comments to make" makes it possible for Lianne to learn to "absorb" the toxic visual content of his performance and transform the assimilated traumatic impression into an antidote against her own fears of mortality (DeLillo 2011:223). While it devastated her in real life, one of the visual traces of Falling Man etched into her memory also made possible her subsequent retention of an image-lesson to be remembered and contemplated, making of her body, to use Hans-Jürgen Heinrichs concept, a "Sprachkörper" (1983) marked by Falling Man's toxic impression like a "photosensitive surface" (DeLillo 2011:223):

She clicked forward. She tried to connect this man to the moment when she'd stood beneath the elevated tracks, nearly three years ago, watching someone prepare to fall from a maintenance platform as the train went past. There were no photographs of that at all. She was the photograph, the photosensitive surface. That nameless body coming down, this was hers to record and absorb. (DeLillo 2011:223)

Here it is important to note that in this deeply significant moment of analytical reflection Lianne conceives of the performance art of Falling Man as a negative image inscribed on her body, forming a picture to be recorded and absorbed, like a visual lesson or parable conveyed by the opposite body of the artist-the archetypal ("nameless") body "coming down," expressing the universal truth that "being human [is] being mortal"' (DeLillo 2011:111). Equally meaningful, Lianne's reference to the centrality of sensation and affect in Falling Man's performance (the permeable self as "photosensitive surface") is an indication that the image to be absorbed and contemplated in recollection is an antidote targeted toward her sensitivity to degeneration and mortality, the all-pervasive anguish that haunts her when she contemplates the ephemerality of her parents, the horrors of $9 / 11$, and the frailty of the Alzheimer's victims with whom she works.

In the final analysis, beyond Lianne's pacified acceptance of illness and mortality, her investigation into the work of Falling Man allows her to project a new "map" of "slow and certain decline," to develop an intuitive capacity to contemplate the movement of degeneration from a different perspective and learn to live with the reality of mortality in order to go on living more fully (DeLillo 2011:125). This new approach to decay and mortality marks Lianne's final accession to a condition of "happy forgetting" (Ricoeur 2004:494 ff.), a state of near-beatitude that is radically different from 
the tormented ruminations on (and identification with) the reality of physical and mental degeneration that she has always found "hard[...] to accept" and "difficult to see":

The truth was mapped in slow and certain decline. Each member of the group lived in this knowledge. Lianne found it hardest to accept in the case of Carmen G.... Lianne herself, bearing her father's mark, the potential toll of plaque and twisted filaments, had to look at this woman and see the crime of it, the loss of memory, personality and identity, the lapse into eventual protein stupor. (DeLillo 2011:125; my emphasis)

Lianne watched her [mother]. It was difficult to see her fitted so steadfastly to a piece of furniture, resigned and unstirring, the energetic arbiter of her daughter's life, ever discerning, the woman who'd given birth to the word beautiful, for what excites admiration in art, ideas, objects, in the faces of men and women, the mind of a child. All this dwindling to a human breath.

(DeLillo 2011:48)

As Falling Man moves toward Lianne's epiphanic moment inside the church, the urge to tame the unruly human power of recollection in order to achieve the right remembering gradually gives way to a healthy imperative determined by the need of the ego to survive and affirm its desire to live and establish a meaningful link to humankind: the need to reach a measure of healthy forgetting by exorcising the future of the fears and traumas of the past. This newly regained state of equanimity culminates in another redeeming moment of intuition during which Lianne decides to expose herself to yet another antidote: by deciding to seek a moment of contemplation in a church, Lianne also decides to face the dead, to accept their presence and, more importantly, to perceive the possibility of a relationship between the living and the dead that is based on communion rather than fear.

\section{CONCLUSION}

\section{To Philosophize is to Learn to Die}

It is therefore with a deliberate intention to learn to make herself at home among the dead that Lianne enters the final phase of the grief process and begins to envision the possibility of putting past fears and traumas behind her (the right forgetting). Having accomplished a momentous act of self-empowerment through her analytical confrontation with Falling Man, she finds herself at last ready to embark upon her moment of enchanted thinking: $:^{28}$ the epiphanic revelation in the church, a sacred space of the shared and the common that brings a measure of peace to the heart of a woman who had her metaphysical "doubts" about the religious dimension of churches but is now beginning to explore their communal significance and the sense of anchoring and continuity it brings:

She was stuck with her doubt but liked sitting in church. She went early, before mass began, to be alone for a while, to feel the calm that marks a presence outside the nonstop riffs of the waking mind. It was not something godlike she felt but only a sense of others. Others bring us closer. Church brings us closer. What did she feel here? She felt the dead, hers and unknown others. (DeLillo 2011:233)

Although Lianne's core of metaphysical skepticism contrasts greatly with the divine imperative she recalls-"This Book is not to be doubted"-there is great validity and certainly much peace in the spirit of commonality that she discovers when she begins to commune with the "presence" of the dead (DeLillo 2011:233). As she consciously decides to meditate on and communicate with the dead dwelling in the walls of the church, her experience is radically different from the uncanny revulsion toward the presence of death that takes hold of Keith when he returns near Ground Zero. $^{29}$ Instead of fear and revulsion, Lianne experiences a sense of pacified anchoring very much akin to her mother's feeling in another pacifying temple of remembering and contemplation: the museum. In a moment of Swedenborgian insight, Lianne finds that there is meaning in both acts, that there is finality and a core of self-validation that allows her to enter a horizon

\footnotetext{
${ }^{28}$ I am thinking here of Max Weber's Entzauberung der Welt-"the elimination of magic from the world" (1992:61 ff.). In light of Weber's concept, we can speak of Lianne's communion with the dead as a form of reenchantment of the world in Morris Berman's sense (1981).

${ }^{29}$ "Since practically all of us still think as savages do on this topic, it is no matter for surprise that the primitive fear of the dead is still so strong within us and always ready to come to the surface at any opportunity. Most likely our fear stil contains the old belief that the deceased becomes the enemy of his survivor and wants to carry him off to share his new life with him. Considering our unchanged attitude towards death, we might rather inquire what has become of the repression, that necessary condition for enabling a primitive feeling to recur in the shape of an uncanny effect. But repression is there, too" (Freud 2003:13).
} 
where she can project herself onto a plane far greater than her individuality. In exploring this newly discovered plane, Lianne realizes that the broadening of her sense of self is closely related to her new feelings of communion with the dead whose presence she "felt" in the walls of the church (DeLillo 2011:233).

The resulting effect of this connection to the dead contrasts greatly with Lianne's customary restlessness and persistent sense of existential isolation in the universe: her feelings of unease about the vicissitudes of the body in a world governed by the imperatives of genetic determinism and her sensation of a "dispiriting chill" in relation to the dead (DeLillo 2011:233). As she sits in contemplation, absorbing the mood of the church, this core of anxiety gives way to a feeling of benevolence coming not only from the dead who inhabit this place, but also from all the dead, creating a feeling of benevolence coming from the world as a whole:

This is what she'd always felt in churches.... She felt the dead in the walls, over decades and centuries. There was no dispiriting chill in this. It was a comfort, feeling their presence, the dead she'd loved and all the faceless others who'd filled a thousand churches. They brought intimacy and ease, the human ruins that lie in crypts and vaults or buried in churchyard plots.... Se was always the first, always seated toward the rear, breathing the dead in candlewax and incense. (DeLillo 2011:233-34)

With the metaphoric link between the vestigial architectural ruins of a civilization and the dead as "human ruins" for the living to contemplate, Lianne comes full circle, finding not only a space of commemoration in the memory of the dead, but also a foundation for strength and peace in the world (DeLillo 2011:233). Accordingly, she finds herself communing in her mind and using one of its most ambiguous instruments (the imagination) in order to conceive, once again, a space of projection-an imaginary scene in which she contemplates the dead in the same way one contemplates venerated "ruins" charged with traces of cultural significance. Suspended between past and present, living and dead, being and un-being, Lianne-once again thanks to the imaginationmanages to conjure up a vision of her own mother as one of the venerable dead that she is "breathing" in the air: "Her mother had a mane of white hair at the end, the body slowly broken, haunted by strokes, blood in the eyes. She was drifting into spirit life. She was a spirit woman now, barely able to make a sound that might pass for a word. She lay shrunken in bed, all that was left of her framed by the long straight hair, frosted white in sunlight, beautiful and otherworldly" (DeLillo $2011: 234)$. This pacified anchoring of the imagination in the past while it communes with the dead as "otherworldly" monuments contrasts greatly with Keith's experience: his uncanny encounter with the dead near Ground Zero followed by his rupture with the traumatizing past and with the dead-a deliberate mental and moral decision to project his existence in the future beyond any form of engagement of his past.

The differences between Lianne and her husband are also significant in terms of personal narrative trajectory. Lianne experiences a linear evolution which, translated into temporal experience, is radically different form the shocking cyclicality that tortures her husband's consciousness and with which we are confronted at novel's end. The temporal unfolding of her crisis in the narrative is defined by three important factors: a heuristic engagement of her fears and her trauma; an analytical approach to the hectic flow of information generated by the 9/11 tragedy; and a conversion of the relentless movement of history itself into a progressive personal experience that culminates in her investigation of the historical role of Falling Man. Consequently, because of her heuristic approach to trauma and crisis, Lianne finds herself gradually using the dynamic of grief itself in order to find a natural way out of it, affirming the needs of her ego and even achieving a measure of enchanted thinking as she uses her imagination to project a world of benevolent communion with the dead, a world of continuity between the realm of the living and the realm of the dead. Thanks to these efforts, she now finds herself inhabiting a city that she is learning to cherish through deliberate meditative acts of communing with the past; through self-founded rites of contemplation that allow her to quite literally breathe the meaningful emanations of collective memory in every one of its cherished places, the memory of the men and the women who made New York City what it is. Through these beatific auguries of innocence, of a self at last reconciled to its corporeal inheritance and to the vicissitudes of the world, Lianne manages to direct the movement of her new enchanted consciousness inward in order to achieve an ultimate reconciliation to her body. In one last symbolic moment that definitively seals her triumph, she realizes that the same state of pacified 
communion that she has learned to discern in the outer world has now turned inward, allowing her to feel quite literally comfortable in her own skin and to achieve one final gesture of transcendence: acceptance of her body with all the familial history that lies coded in it"everything it carried, inside and out, identity and memory and human heat.... She was ready to be alone, in reliable calm, she and the kid, the way they were before the planes appeared that day, silver crossing blue" (DeLillo 2011:236).

\section{REFERENCES}

Aptizsch, Julia. 2010. "The Art of Terror-the Terror of Art: DeLillo's Still Life of 9/11, Girgio Morandi, Gerhard Richter, and Performance art." Pp. 93-108 in Terrorism, Media, and the Ethics of Fiction: Transatlantic Perspectives on Don DeLillo, edited by P. Schneck and P. Schweighauser London: Bloomsbury.

Armitage, John. 1999. "From Modernism to Hypermodernism and Beyond: An Interview with Paul Virilio." Theory, Culture, and Society 16(5-6):25-55. http://dx.doi.org/10.1177/02632769922050854

Badiou, Alain. 2004. Infinite Thought: Truth and the Return of Philosophy, translated by O. Feltham and J. Clemens. London: Continuum.

Bataille, Georges. 1967. La Part maudite: précédé de la notion de dépense. Paris: Éditions de Minuit.

Baudrillard, Jean. 1976. Pour une critique de l'économie politique du signe. Paris: Gallimard.

Baudrillard, Jean. 1981. Simulacres et simulation. Paris: Galilée.

Baudrillard, Jean. 1983. Les stratégies fatales. Paris: Grasset \& Fasquelle.

Baudrillard, Jean. 1986. Amérique. Paris: Grasset.

Baudrillard, Jean. 1990. La transparence du mal: essai sur les phénomènes extrêmes. Paris: Galilée.

Bayman, Henry. 2003. The Secrets of Islam: Love and Law in the Religion of Ethics. Berkeley: North Atlantic Books.

Berman, Marshall. 1988. All that is Solid Melts into Air: The Experience of Modernity. London: Penguin Books.

Berman, Morris. 1981. The Reenchantment of the World. Ithaca: Cornell University Press.

Blanchot, Maurice. 1953. "Sade." Pp. 687-732 in Sade, edited by J. J. Pauvert. Paris: Le Club Français du Livre.

Blanchot, Maurice. 1980. L'écriture du désastre. Paris: Gallimard.

Borradori, Giovanna. 2004. Philosophy in a Time of Terror: Dialogues with Jürgen Habermas and Jacques Derrida. Chicago: University of Chicago Press.

Caillois, Roger. 1967. Les jeux et les hommes. Paris: Gallimard.

Caporale Bizzini, Silvia. 2010. "Grieving and memory in Don DeLillo's Falling Man." Pp. 40-50 in Terrorism, Media, and the Ethics of Fiction: Transatlantic Perspectives on Don DeLillo, edited by P. Schneck and P. Schweighauser London: Bloomsbury.

Certeau, Michel de. 1973. L'Absent de l'histoire. Paris: Mame.

Certeau, Michel de. 1992. The Writing of History, translated by T. Conley. New York: Columbia University Press.

DeLillo, Don. 2011. Falling Man. London: Picador.

DeLillo, Don. 2001. "In the Ruins of the Future: Reflections on Terror and Loss in the Shadow of September." Harper's, December (2001), pp. 33-40.

Derrida, Jacques. 1967. L'écriture et la différence. Paris: Seuil.
Derrida, Jacques. 1981. Dissemination, translated by B. Johnson. Chicago: University of Chicago Press.

Derrida, Jacques. 2001. The Work of Mourning, translated by P. A Brault and M. Nass. Chicago: University of Chicago Press.

Derrida, Jacques. 2006. Spectres de Marx:_'état de la dette, le travail du deuil et la nouvelle internationale. Paris: Galilée.

Diken, Bülent. 2009. Nihilism. London: Routledge.

Dupuy, Jean-Pierre. 2002. Pour un catastrophisme éclairé: quand l'impossible est certain. Paris: Seuil.

Eliot, T. S. 1971. Four quartets. New York: Harcourt Brace Jovanovich.

Freud, Sigmund. 1936. The Problem of Anxiety, translated by H. A. Bunker. New York: W. W. Norton.

Freud S. 1941. "Splitting of the Ego in the Defensive Process," translated by James Strachey. International Journal of Psychoanalysis 22:65.

Freud, Sigmund. 1978. Mourning and melancholia. Pp. 237-58 in The Standard Edition of the Complete Psychological Works of Sigmund Freud. Vol. 14, translated by J. Strachey. London: The Hogarth Press.

Freud, Sigmund. 2003. The Uncanny, translated by D. McLintock. London: Penguin.

Frye, Northrop. 1957. Anatomy of Criticism: Four Essays. Princeton: Princeton University Press.

Gourley, James. 2013. Terrorism and Temporality in the Works of Thomas Pynchon and Don DeLillo. London: Bloomsbury.

Goux, Jean-Joseph. 1978. Les Iconoclastes. Paris: Seuil.

Goux, Jean-Joseph. 1990. "General Economics and Postmodern Capitalism." Yale French Studies 78:206-224. http://dx.doi.org/10.2307/2930123

Heinrichs, Hans-Jürgen. 1983. Sprachkörper: zu Claude Lévi-Strauss und Jacques Lacan. Frankfurt am Main: Qumran.

Hodgkin, Katharine and Susannah Radstone. 2006. Memory, History, Nation: Contested Pasts. New Brunswick, NJ: Transaction Publishers.

Jameson, Fredric. 1974. The Prison-House of Language: A Critical Account of Structuralism and Russian Formalism. Princeton: Princeton University Press.

Kermode, Frank. 1968. The Sense of an Ending. Oxford: Oxford University Press.

Kristeva, Julia. 1980a. "Postmodernism?" Bucknell Review 25(2):136-41.

Kristeva, Julia. 1980b. Pouvoirs de l'horreur: essai sur l'abjection. Paris: Seuil.

Lacan, Jacques. 1966. Écrits. Paris: Seuil.

Lacan, Jacques. 1973. Le Séminaire de Jacques Lacan: les quatre concepts fondamentaux de la psychanalyse. Paris: Seuil.

Lefort Claude. 1978. Les Formes de l'histoire: essais d'anthropologie politique. Paris: Gallimard.

Leps, Marie-Christine. 2010. "Falling Man: Performing Fiction." Pp. 184-203 in Terrorism, Media, and the Ethics of Fiction: Transatlantic Perspectives on Don DeLillo, edited by P. Schneck and P. Schweighauser London: Bloomsbury.

Levinas, Emmanuel. 1961. Totalité et infini: essai sur l'extériorité The Hague: Martinus Nijhoff.

Levinas, Emmanuel. 1982. Éthique et infini: dialogues avec Philippe Nemo. Paris: Fayard.

Luhmann, Niklas. 2014. Vertrauen. Ein mechanismus der reduktion sozialer kompläxität. Stuttgart: UTB.

Lyotard, Jean-François. 1985. The Postmodern Condition: A Report on Knowledge, translated by $\mathrm{G}$. Bennington and B. Massumi. Minneapolis: The University of Minnesota Press.

Lyotard, Jean-François. 1991. "Logos and techne, or telegraphy." Pp. 47-57 in The Inhuman: Reflections on Time, translated by G. Bennington and R. Bowlby. Cambridge: Polity Press. 
Lyotard, Jean-François. 1991. "Representation, Presentation, Unpresentable." Pp. 119-28 in The Inhuman: Reflections on Time, translated by G. Bennington and R. Bowlby. Cambridge: Polity Press.

Mallarmé, Stéphane. 1914. Poème: un Coup de dés jamais n'abolira le hasard. Paris: Gallimard.

Martín Salván P. 2010. "Terror, Asceticism, and Epigrammatic Writing in Don DeLillo's Fiction." Pp. 145-57 in Terrorism, Media, and the Ethics of Fiction: Transatlantic Perspectives on Don DeLillo, edited by P. Schneck and P. Schweighauser. London: Bloomsbury.

Marx, Karl and Friedrich Engels. 1969. Manifesto of the Communist Party. Pp. 98-137 in Marx/Engels: Selected Works. Vol. 1, translated by S. Moore. Moscow: Progress Publishers.

Montaigne, Michel de. 2009. "That to Study Philosophy is to Learn to Die. Pp. 187-218 in Essays, translated by C. Cotton, edited by W. C. Hazlitt. Auckland: The Floating Press.

Nietzsche, Friedrich. 1989. On the Genealogy of Morals and Ecce Homo, translated by W. Kaufmann, edited by W. Kaufmann New York: Vintage.

Rich, Adrienne. 1984. "Diving into the Wreck." Pp. 162-64 in The Fact of a Doorframe. New York: W. W. Norton.
Ricoeur Paul. 2004. Memory, History, Forgetting, translated by $\mathrm{K}$. Blamey and D. Pellauer. Chicago: University of Chicago Press.

Singh, Rashmi. 2011. Hamas and Suicide Terrorism: Multi-Causal and Multi-Level Approaches. Oxford: Routledge.

Virilio, Paul. 1977. "L'État d'urgence ou du lieu d'élection au lieu d'éjection." Traverses 9 (November):60-74.

Virilio, Paul. 1988. La Machine de vision. Paris: Galilée.

Virilio, Paul. 1989. Esthétique de la disparition. Paris: Galilée.

Weber, Max. 1992. The Protestant Ethic and the Spirit of Capitalism. London: Routledge.

Wolfe, Cary. 2008. "The Digital, the Analog, and the Spectral: Ecographies from My Life in the Bush of Ghosts." Angelak 13(1):85-94 http://dx.doi.org/10.1080/09697250802156083

Zafirovski, Milan and Daniel G. Rodeheaver. 2013. Modernity and Terrorism: From Anti-Modernity to Modern Global Terror. Leiden: Brill. http://dx.doi.org/10.1163/9789004242883

Žižek, Slavoj. 1989. The Sublime Object of Ideology. London: Verso Books.

\section{DOI: http://dx.doi.org/10.6000/2371-1655.2016.02.09}

(C) 2016 Salah el Moncef; Licensee Lifescience Global.

This is an open access article licensed under the terms of the Creative Commons Attribution Non-Commercial License (http://creativecommons.org/licenses/by-nc/3.0/) which permits unrestricted, non-commercial use, distribution and reproduction in any medium, provided the work is properly cited. 